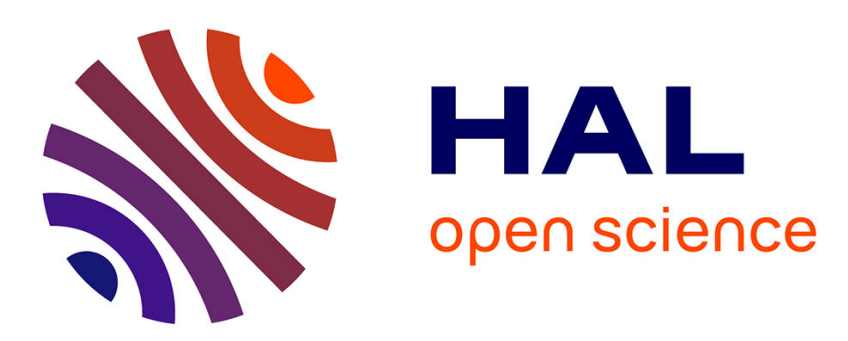

\title{
Storage conditions and eruptive dynamics of central versus flank eruptions in volcanic islands: the case of Tenerife (Canary Islands, Spain)
}

\author{
Joan Andújar, Fidel Costa, Bruno Scaillet
}

\section{- To cite this version:}

Joan Andújar, Fidel Costa, Bruno Scaillet. Storage conditions and eruptive dynamics of central versus flank eruptions in volcanic islands: the case of Tenerife (Canary Islands, Spain). Journal of Volcanology and Geothermal Research, 2013, 260, pp.62-79. 10.1016/j.jvolgeores.2013.05.004 . insu-00827722

HAL Id: insu-00827722

https://hal-insu.archives-ouvertes.fr/insu-00827722

Submitted on 29 May 2013

HAL is a multi-disciplinary open access archive for the deposit and dissemination of scientific research documents, whether they are published or not. The documents may come from teaching and research institutions in France or abroad, or from public or private research centers.
L'archive ouverte pluridisciplinaire HAL, est destinée au dépôt et à la diffusion de documents scientifiques de niveau recherche, publiés ou non, émanant des établissements d'enseignement et de recherche français ou étrangers, des laboratoires publics ou privés. 


\section{Storage conditions and eruptive dynamics of central versus flank eruptions in volcanic islands: the case of Tenerife (Canary Islands, Spain)}

Joan Andújar ${ }^{\mathrm{a},{ }^{*},}$, Fidel Costa ${ }^{\mathrm{b}}$, Bruno Scaillet $^{\mathrm{a}}$

a. Université d'Orléans, ISTO, UMR 7327, 45071, Orléans, France ; CNRS/INSU, ISTO, UMR 7327, 45071 Orléans, France ; BRGM, ISTO, UMR 7327, BP 36009, 45060 Orléans, France.

b. Earth Observatory of Singapore, Nanyang Technological University, Singapore 639798, Singapore

* Corresponding author: Joan Andújar.

phone number: (+33) 238255387

Fax: (+33) 0238636488

e-mail address: Juan.Andujar@cnrs-orleans.fr

Fidel Costa e-mail address: fcosta@ntu.edu.sg

Bruno Scaillet e-mail address: bscaille@cnrs-orleans.fr

KEY WORDS: Phase equilibria, phonolite, experimental petrology, eruptive dynamic, flank eruption, central eruption, Tenerife, Teide. 


\begin{abstract}
We report the results of phase equilibrium experiments on a phonolite produced during one of the most voluminous flank eruptions (ca. $1 \mathrm{~km}^{3}$ ) of the Teide-Pico Viejo complex (Tenerife Island). Combined with previous experimental and volcanological data we address the factors that control the structure of the phonolitic plumbing system of TeidePico Viejo stratovolcanoes. The Roques Blancos phonolite erupted ca $1800 \mathrm{BP}$ and contains $\sim 14$ wt $\%$ phenocrysts, mainly anorthoclase, biotite, magnetite, diopside and lesser amounts of ilmenite. Crystallization experiments were performed at temperatures of $900^{\circ} \mathrm{C}, 850^{\circ} \mathrm{C}$ and $800^{\circ} \mathrm{C}$, in the pressure range $200 \mathrm{MPa}$ to $50 \mathrm{MPa}$. The oxygen fugacity $\left(f \mathrm{O}_{2}\right)$ was varied between $\mathrm{NNO}+0.3(0.3 \mathrm{log}$ units above to the $\mathrm{Ni}-\mathrm{NiO}$ solid buffer) to NNO-2, whilst dissolved water contents varied from $7 \mathrm{wt} \%$ to $1.5 \mathrm{wt} \%$. The comparison between natural and experimental phase proportions and compositions, including glass, indicates that the phonolite magma was stored prior to eruption at $900 \pm 15^{\circ} \mathrm{C}, 50 \pm 15 \mathrm{MPa}$, with about $2.2 \mathrm{wt} \% \mathrm{H}_{2} \mathrm{O}$ dissolved in the melt, at an oxygen fugacity of NNO-0.5 $( \pm 0.5)$. The difference in composition between the rim and the cores of the natural anorthoclase phenocrysts suggests that the phonolite was heated by about $50^{\circ} \mathrm{C}$ before the eruption, upon intrusion of a hotter tephriphonolitic magma. The comparison between the storage conditions of Roques Blancos and those inferred for other phonolites of the Teide-Pico Viejo volcanic complex shows that flank eruptions are fed by reservoirs located at relatively shallow depths $(1-2 \mathrm{~km})$ compared to those feeding Teide central eruptions $(5 \mathrm{~km})$.
\end{abstract}




\section{Introduction}

Understanding the plumbing system beneath volcanic edifices is crucial to constrain the parameters that control the evolution of ascending magmas and for anticipating the future eruptive behaviour of the volcano. The use of dense geophysical and geochemical monitoring networks deployed on highly active volcanes (i.e., Etna volcano; Bonacorso et al. 2004) allows to gain information concerning the movement and likely levels of magma storage. Monitoring data combined with petrological studies (e.g., Kahl et al., 2011) enables to better reconstruct the geometry of the plumbing system beneath the volcanic edifice of an on-going eruption, and thus construct more robust eruptive scenarios in the short time frame.

However, real time monitoring techniques do not easily allow to understand the mid (e.g., hundred years) to long-term (thousands of year or more) evolution of the volcanic system, or the variation of eruptive dynamics (ie.; variation in eruptive style during a single event or between eruptions) with time. This is particularly true for volcanoes with low eruption frequency, which are characterised by long periods of dormancy during which little, if any, geophysical or geochemical signals can be recorded, making their interpretations difficult whenever the system awakes. The volcanological record often bears witness of significant variations in the eruptive styles (alternation between sustained explosive Plinian eruptions, transient explosive and purely effusive activity), and in vent location (central and flank eruptions; i.e., Corsaro et al., 2007; Ablay and Martí, 2000), which may in part reflect the complexity of the plumbing system. In such cases, only the study of past eruptions and the distribution of eruptive centres can provide insights on both the long-term evolution of the volcanic edifices and on the factors that control the eruptive dynamic.

This is the case of Tenerife in the Canary Islands, a volcanic island that has slowly evolved from a primitive to highly differentiated edifice. The spatial and temporal distribution of its recent volcanism demonstrates that the island is highly active (Martí et al., 2008), yet eruptions are spaced in time, events being separated by x100-1000 years (Carracedo et al., 2007; Martí et al., 2008). Tenerife island hosts the active Teide-Pico Viejo volcano, which is characterised by emission of magmas from either central (Teide main vent) or flank vents. Despite a diversity of eruptive styles during the last 35 kyrs, erupted magmas have similar phonolitic compositions (Ablay et al., 1995; Ablay et al., 1998; Rodríguez-Badiola et al, 2006; Carracedo and Rodríguez- 
Badiola, 2006; Carracedo et al., 2007; Martí et al., 2008; Wiesmaier et al., 2012). Recent numerical simulations performed on this volcanic complex suggest that the main factors controlling the vent location at Teide-Pico Viejo are the shape of the reservoir and the stress field distribution around it which can be affected by the presence of a second magma chamber (Martí and Geyer, 2009). Such a possibility is supported by the petrological and geochronological data of recent phonolitic eruptions (Ablay et al., 1998; Carracedo et al., 2007; Andújar and Scaillet, 2012a). The relative position between the reservoirs also exerts an important control on the final trajectory of the injected dykes and hence in the final location (central or flank) of the vent (Martí and Geyer, 2009). Since the depths of such reservoirs feeding flank eruptions at Teide-Pico Viejo are poorly constrained (Andújar and Scaillet, 2012a), we have performed phase equilibrium experiments on a representative phonolite of the Roques Blancos, one of the most recent flank dome eruptions occurred at this volcanic island.

\section{Geological setting}

The evolution and stratigraphy of Teide stratovolcano have been the focus of several studies (i.e., Araña, 1971; Martí et al., 1994; Ablay et al., 1998; Martí and Gudmunsson, 2000; Ablay and Martí, 2000; Rodríguez-Badiola et al., 2006; Carracedo et al., 2007; Wiesmaier et al., 2012). We first summarise the main aspects concerning the structural and volcanological evolution of the actual volcanic complex of Teide and Pico Viejo stratovolcanoes.

The post-shield volcanism of Tenerife has been characterised by the repetitive development of compositionally evolved centres including 3 caldera collapses (Martí et al., 1994; Ablay et al., 1998; Carracedo et al., 2007). The products of the last and most recent eruptive cycle (<200 kyr) built the twin stratovolcano of Teide and Pico Viejo (TPV). The most recent volcanism includes that of the main T-PV cones which is characterised by the emission of significant volumes of phonolitic magmas, and the volumetrically smaller and more mafic eruptions from the rifts (Martí et al., 1994; Ablay and Martí, 2000; Carracedo et al., 2007; Martí et al., 2008). The extrusion of mafic to intermediate magmas dominated the first stages of the construction of the T-PV volcanic complex until $35 \mathrm{ka}$ ago. Then, phonolitic magmas started to erupt and became the predominant erupted composition till today (Ablay et al., 1998; Rodríguez-Badiola et al., 2006; Carracedo et al., 2007). During the last $35 \mathrm{ka}$, magma emission occurred 
either at central Pico Teide or from the numerous flank vents (up to 10), of which the Montaña Blanca, Roques Blancos, Pico Cabras and Montaña Rajada events are the most important ones (Fig.1b; Ablay and Martí, 2000; Rodríguez-Badiola et al., 2006; Carracedo et al., 2007).

Although such satellite eruptions are volumetrically smaller (generally $\leq 0.2$ $\mathrm{km}^{3}$ ) relative to those from the central Teide vent (generally $\geq 0.3 \mathrm{~km}^{3}$ ), they are characterised by a sustained explosive activity and fall-out deposits together with the emission of thick lava flows (García et al., 2012; Martí et al., 2012). The explosive activity of these flank eruptions includes the sub-Plinian event of Montaña Blanca (Ablay et al., 1995; Ablay and Martí, 2000; Rodríguez-Badiola et al., 2006; Martí et al., 2008; Andújar and Scaillet, 2012a), and El Boqueron flank eruption (García et al., 2012). In addition to these episodes, two more phonolitic explosive flank events have been recently identified (Martí et al., 2012; O. García unpublished data). In contrast, phonolitic volcanism from Teide proper is less explosive, and alternates between pure effusive activity that generated thick lava flows and transient explosive activity, which has produced scoria and spatter deposits (Ablay and Martí, 2000; Martí et al., 2008). However, it is unclear why some eruptions proceed through the central Teide cone while others occur on its flanks, and how does this relate to the more explosive activity from the flank events. Here we provide petrological constraints to explain these observations by determining the pre-eruptive conditions of the Roques Blancos dome, one of the most significant flank eruptions in the recent history of Teide-Pico Viejo volcanic complex, in terms of the erupted volume and extension of the lava flows (Fig.1; Balcells and Hernández-Pacheco, 1989; Carracedo and Rodríguez-Badiola, 2006; Martí et al, 2008).

\section{The Roques Blancos eruption}

The Roques Blancos event occurred in two eruptive episodes, the oldest one (1974 BP) from a satellite dome located at the NW side of Pico Viejo stratovolcano at about $2800 \mathrm{~m}$ asl (above sea level) and, a second eruption occurring at $1714 \mathrm{BP}$ from a dome located a few hundred meters below the first vent (2500-2600 m asl; Fig. 1; Balcells and Hernández-Pacheco, 1989; Carracedo and Rodríguez-Badiola, 2006; Carracedo et al., 2007). These eruptions emitted about 0.8 to $1 \mathrm{~km}^{3}$ of highly evolved phonolitic magma which covered a surface of about $15 \mathrm{~km}^{2}$ and generated lava that flowed over a height difference of about $3000 \mathrm{~m}$, reaching the seaside in the Northern 
part of Tenerife Island (Carracedo and Rodríguez-Badiola 2006; Martí et al., 2012). Both phonolitic products are petrologically and geochemically very similar (Fig.1; Balcells and Hernández-Pacheco, 1989; Ablay, 1997; Ablay et al., 1998; Ablay and Martí, 2000; Carracedo and Rodríguez-Badiola, 2006; Carracedo et al., 2007; Martí et al., 2008).

\subsection{Pre-eruptive conditions of Roques Blancos magma from petrological observations}

Several blocks of lava were collected at $\sim 2500 \mathrm{~m}$ asl from one of the main lava flows of the 1714 BP Roques Blancos youngest dome (Fig.1). The freshest rock blocks were selected as starting material for performing phase equilibrium experiments, wholerock, and electron microprobe analyses (EMPA) of the different phases (Table 1). The bulk-rock composition, as determined by ICP-MS, is a typical phonolite (59.4 wt\% $\mathrm{SiO}_{2}, 15.4 \mathrm{Na}_{2} \mathrm{O}+\mathrm{K}_{2} \mathrm{O}$; Le Maitre et al., 1989; Table 1) representative of the Roques Blancos flows (Balcells and Hernández-Pacheco, 1989; Ablay et al., 1998; Carracedo and Rodríguez-Badiola, 2006).

Modal point counting of three thin sections (3000 points each) was combined with mineral densities to obtain the weight percent (wt\%) of the different phases. The sample has $\sim 14 \mathrm{wt} \%$ phenocrysts, mainly anorthoclase (13.7 wt \%; $\mathrm{An}_{4-3}, \mathrm{Ab}_{69-65}, \mathrm{Or}_{32-}$ 27), minor amounts of biotite (0.3 wt\%; $\left.\mathrm{Mg} \# 62-63 ; \mathrm{Mg} \#=100\left[\mathrm{Mg} /\left(\mathrm{Mg}+\mathrm{Fe}^{*}\right)\right]\right)$, magnetite (0.3 wt\%; Mg\# 5), diopside (0.1 wt\%; Mg\# 68-70; $\mathrm{En}_{39-41}, \mathrm{Fs}_{9-11}, \mathrm{Wo}_{50}$ ) and ilmenite $(0.1 \mathrm{wt} \%)$. Phenocrysts are set in a highly crystalline groundmass made of microlites of alkali feldspar, magnetite, clinopyroxene, in addition to glass (Table 1, Fig.2). Mass-balance calculations were used to obtain the composition of the residual melt that was in equilibrium with phenocrysts by combining the whole-rock and mineral phase compositions. As anticipated owing to the low phenocryst content, the resulting melt is phonolitic $\left(59.2 \mathrm{wt} \% \mathrm{SiO}_{2}, 17.0 \mathrm{wt} \% \mathrm{Na}_{2} \mathrm{O}+\mathrm{K}_{2} \mathrm{O}\right)$ with a composition similar to that of the bulk-rock (Table 1).

Backscattered electron images (BSE) of the sample show that most anorthoclase phenocrysts show prominent bright rims and dissolution surfaces, while clinopyroxene displays oscillatory zoning and some dissolution surfaces, and some $\mathrm{Fe}-\mathrm{Ti}$ oxides present exsolution textures whereas others do not. In contrast, biotite appears to be homogeneous on BSE. Elemental mapping of $\mathrm{Ba}$ and EMPA traverses of anorthoclase reveal core to rim zonations (cores at $\mathrm{An}_{2.5-4}$ and $\mathrm{BaO}$ 0.1-0.2 wt\%, toward more 
calcium-and Ba-rich rims of $\mathrm{An}_{7-8}$ and up to $0.4 \mathrm{wt} \%$, respectively; Fig.3). In detail, many crystals show complex rims: (1) the outermost rims (e.g., last 10-20 $\mu$ m) have extremely high $\mathrm{Fe}$ and $\mathrm{Ti}$, high $\mathrm{Ca}$, and very low $\mathrm{Ba}$, possibly resulting from fast growth, during which incompatible elements are incorporated at higher than equilibrium concentrations, and compatible ones at lower than equilibrium concentrations (e.g., Albarède and Bottinga, 1972). (2) Inside this outer rim, crystals still have a high Fe, Ti, $\mathrm{Ca}$ and $\mathrm{Ba}$ zones, compared to the core. There is a dissolution zone between the inner part and the outer rims of the crystals. These observations suggests that there was a change in the pre-eruptive conditions just prior to eruption, ie magma reheating upon a recharge event, followed by a fast crystal growth stage.

Pre-eruptive temperatures and $f \mathrm{O}_{2}$ for the $1714 \mathrm{BP}$ Roques Blancos phonolite were determined by using six co-existing Fe-Ti oxides and the thermo-oxybarometric model of Sauerzapf et al. (2008). Results yield temperatures of $895 \pm 5^{\circ} \mathrm{C}$ and a $\log f \mathrm{O}_{2}$ of -12.2 , equivalent to an oxygen fugacity of $0.2 \log$ units below the $\mathrm{Ni}-\mathrm{NiO}$ solid buffer (NNO-0.2; Table 1). As there are currently no constraints on storage pressure or volatile content of the Roques Blancos phonolite, the ranges of pressure and volatile content covered in the experiments were guided by previous results obtained on similar compositions of the same volcanic complex (Andújar et al., 2010; Andújar and Scaillet, 2012a).

\section{Experimental work}

We have performed phase-equilibrium experiments following a methodology similar to that used for constraining the storage conditions of active volcanoes such as Stromboli, Vesuvius, St. Pedro volcanoes (e.g., Di Carlo et al., 2006; Scaillet et al., 2008; Costa et al., 2004) and taking in account the recommendations in the application of phase equilibrium experiments to volcanic rocks as laid down by Pichavant et al. (2007).

\subsection{Preparation of the starting material}

Pieces of the phonolitic lava were finely ground in an agate mortar and then melted in a Pt crucible at $1400^{\circ} \mathrm{C}$ during 5 hours in open-air atmosphere. The sample was quenched in a water container at room temperature, glass chips recovered ground again and re-melted. Chips of the resulting starting glass were analysed by the EMP and compared to the bulk-rock composition, showing that it is homogeneous with no 
significant $\mathrm{Na}$ or $\mathrm{Fe}$ loss compared to the starting rock (Table 1). The dry glass was then ground for obtaining a powder that was used as starting material for hydrothermal experiments and stored in an oven at $120^{\circ} \mathrm{C}$.

\subsection{Experimental equipment and procedures}

A total of 55 crystallization experiments were performed at the experimental laboratory of ISTO (Orléans, France) in a vertically operating Internally Heated Pressure Vessel (IHPV), using Ar as pressurising medium which was mixed with different amounts of $\mathrm{H}_{2}$ at room temperature in order to achieve different $f \mathrm{O}_{2}$ (Scaillet et al., 1992). A transducer calibrated against a Heise Bourdon gauge with an uncertainty of

$\pm 2 \mathrm{MPa}$ was used for recording total pressure. Experiments were performed using double-winding molybdenum and kanthal furnaces which produce near-isothermal conditions (gradient $<2-3^{\circ} \mathrm{C} / \mathrm{cm}$ ) along a $3 \mathrm{~cm}$ long hot spot. S- or K-type thermocouples with an accuracy of $\pm 5^{\circ} \mathrm{C}$ were used to record experimental temperature and a rapid-quench technique was systematically used which allows isobaric quenches at high cooling rates $\left(>100^{\circ} \mathrm{C} / \mathrm{s}\right)$ (e.g., Martel et al., 1999; Di Carlo et al., 2006). In all runs reported here, the drop quench was successful as indicated by the rise in total pressure upon the falling of the sample holder into the cold (bottom) part of the vessel.

Experiments were mainly conducted at $850{ }^{\circ} \mathrm{C}$ and $900{ }^{\circ} \mathrm{C}$, pressures of 200 , 150,100 , and $50 \mathrm{MPa}$ and at $\mathrm{fO}_{2} \sim \mathrm{NNO}+0.3$ to NNO-2. The effect of temperature on phase relationships and compositions was studied by conducting experiments at $800^{\circ} \mathrm{C}$, 200 and $100 \mathrm{MPa}$ at $\sim \mathrm{NNO}$. One run was also performed at NNO-1 at $850{ }^{\circ} \mathrm{C}$ and 100 $\mathrm{MPa}$ so as to study the effect of oxygen fugacity on phase equilibria at this temperature (Table 2).

\subsubsection{Capsule preparation}

$\mathrm{H}_{2} \mathrm{O}$-saturated and undersaturated charges were prepared using $1.5 \mathrm{~cm}$ long, $2.5 \mathrm{~mm}$ inner diameter, $0.2 \mathrm{~mm}$ wall thickness Au capsules. Distilled $\mathrm{H}_{2} \mathrm{O}$ was first loaded, then silver oxalate as the source of $\mathrm{CO}_{2}$ for $\mathrm{H}_{2} \mathrm{O}$-undersaturated charges, and finally the glass powder was introduced. Capsules were weighed and then welded using a graphite arc welder. After welding, capsules were re-weighed and if no significant weight loss occurred (difference $<0.0004 \mathrm{~g}$ ), they were left in an oven for a few hours at $100^{\circ} \mathrm{C}$, to ensure homogeneous $\mathrm{H}_{2} \mathrm{O}$ distribution. In all charges the $\mathrm{H}_{2} \mathrm{O}+\mathrm{CO}_{2}$ mass and fluid/silicate ratio were kept constant $\left(3 \pm 0.5 \mathrm{mg}\right.$ of $\mathrm{H}_{2} \mathrm{O}+\mathrm{CO}_{2}$, and $30 \mathrm{mg}$ silicate). We 
have explored various starting $\mathrm{H}_{2} \mathrm{O} / \mathrm{CO}_{2}$ ratios at a given T-P conditions: $\mathrm{XH}_{2} \mathrm{O}_{\text {in }}$, defined as the $\mathrm{H}_{2} \mathrm{O} /\left(\mathrm{H}_{2} \mathrm{O}+\mathrm{CO}_{2}\right)$ molar ratio, was varied in the range 1-0.48 (Table 2). For each run, one capsule containing a Ni-Pd-O alloy sensor, prepared following the procedure of Taylor et al. (1992), was added to monitor the $f \mathrm{H}_{2}$ during the experiment. A typical run consisted of loading the vessel with six capsules (each with the same starting material but different $\mathrm{XH}_{2} \mathrm{O}_{\text {in }}$ ) and the $\mathrm{Ni}-\mathrm{Pd}-\mathrm{O}$ sensor capsule, all of them experiencing the same T-P- $f \mathrm{H}_{2}$ conditions (Table 2).

Depending on pressure and temperature, the run duration varied between 7 and 18 days (Table 2). Runs were terminated by first using the drop quench device and then switching off the power supply. After the experiment, capsules were checked for leaks, opened, and half of the run product was mounted with epoxy resin and polished for optical observation, and subsequent EMP and SEM analyses. The same procedure was followed for the capsules containing the metallic sensors and the subsequent EMP analysis of the metallic pellet allowed the determination of the $f \mathrm{O}_{2}$ of the system (Pownceby and O’Neill, 1994; see below).

\subsubsection{Water content, $\mathrm{fH}_{2}, \mathrm{fO}_{2}$ in the capsules}

The use of different mixtures of $\mathrm{H}_{2} \mathrm{O}+\mathrm{CO}_{2}$ in the capsules allowed us to explore different water fugacities, hence, different melt $\mathrm{H}_{2} \mathrm{O}$ content in the experiments (Table 2). In experiments conducted at $900^{\circ} \mathrm{C}$ and at $\mathrm{H}_{2} \mathrm{O}$-saturated conditions, the size of glass pools was large enough for determining the amount of dissolved water by Fourier transform infra-red (FTIR) spectroscopy. The composition of the natural phonolite resembles that used by Carroll and Blank (1997) for determining the solubility of water in phonolitic melts. Thus, we have used the same analytical conditions and parameters (e.g., extinction coefficients $\in 5200 \in 4500$ ) to determine the water concentration in the glass (Table 3). The small size of the glass pools in experiments run at $850-800^{\circ} \mathrm{C}$ did not allow for water determination using FTIR. In such cases, we have calculated the water content of the experimental charges by using the $\mathrm{H}_{2} \mathrm{O}$ solubility model of Papale et al. (2006).

Once the water content of the glass in $\mathrm{H}_{2} \mathrm{O}$-saturated charges is known, the water content of charges held at the same temperature and pressure but at $\mathrm{XH}_{2} \mathrm{O}_{\text {in }}<1$, was calculated by multiplying the water content determined at $\mathrm{H}_{2} \mathrm{O}$-saturated conditions by the initial mole fraction of water loaded in the capsule $\left(\mathrm{XH}_{2} \mathrm{O}_{\mathrm{in}}\right.$, Table 2). 
We used the Ni-Pd-O sensors from successful runs to determine the prevailing $f \mathrm{H}_{2}$. The $f \mathrm{O}_{2}$ was then determined by using the dissociation constant of water (Robie et al., 1979) and knowing the $f \mathrm{H}_{2} \mathrm{O}$ at the experimental temperature and pressure. The $f \mathrm{H}_{2} \mathrm{O}$ was calculated as $f \mathrm{H}_{2} \mathrm{O}=\mathrm{XH}_{2} \mathrm{Oin} * f \mathrm{H}_{2} \mathrm{O}^{\circ}$ where $f \mathrm{H}_{2} \mathrm{O}^{\circ}$ is the fugacity of pure water (in bars) at the running temperature and pressure (Burnham et al., 1969). In experiments where the sensors failed, the $f \mathrm{H}_{2}$ was determined using an empirical calibration curve between the $\mathrm{H}_{2}$ pressure added to the autoclave at room temperature and the $f \mathrm{H}_{2}$ retrieved from runs in which the sensor was successful (Table 2).

The experiments were conducted at oxygen fugacities around $\mathrm{NNO} \pm 0.5$. However, as $f \mathrm{O}_{2}$ varies with decreasing activity of water in the melt $\left[\mathrm{aH}_{2} \mathrm{O}\right.$, $\left(\right.$ or $\mathrm{XH}_{2} \mathrm{O}_{\text {in }}$ in the ideal approximation and neglecting the amount of water dissolved in the melt)] at fixed T, P, $f \mathrm{H}_{2}$ (e.g., Scaillet et al., 1995; Freise et al., 2009; Andújar and Scaillet, 2012a), water-undersaturated experiments were effectively run at somewhat lower $\mathrm{fO}_{2}$ (NNO-1 $\pm 0.5 \log$ units ; Table 2). We have also conducted experiments at $850^{\circ} \mathrm{C}$ and 100 $\mathrm{MPa}$ and at an $\mathrm{fO}_{2} 1 \mathrm{log}$ unit lower than the average conditions so as to determine the effects of $f \mathrm{O}_{2}$ on phase relationships.

\subsubsection{Analytical techniques}

Phase compositions were determined using a Cameca SX-50 electron microprobe with an accelerating voltage of $15 \mathrm{kV}$, sample current of $6 \mathrm{nA}$, and a counting time of $10 \mathrm{~s}$. A defocused beam of $10 \mu \mathrm{m}$ was used for glasses and a focused beam for minerals. Alkali migration was corrected by using secondary phonolitic standards with a composition similar to the natural obsidian and with known dissolved water contents of $10 \mathrm{wt} \%, 6 \mathrm{wt} \%$ and $1.5 \mathrm{wt} \%$ respectively (Andújar et al., 2008, 2010). Mass-balance calculations were used to obtain the phase proportions of the charges using the bulk composition of the starting material and the composition the phases (Table 2).

Experiments conducted at $900^{\circ} \mathrm{C}$ and $850^{\circ} \mathrm{C}$ had small crystals $(<10-5 \mu \mathrm{m})$ which did not allow to obtain EMP analyses free of glass contamination (i.e.; clinopyroxene with $\mathrm{K}_{2} \mathrm{O}$ higher than $0.1 \mathrm{wt} \%$, see below). The glass contribution was removed by subtracting different amounts of glass until the mineral analysis agreed with the corresponding structural formula. We were able to use SEM-EDS to identify all minerals present: alkali feldspar, biotite, magnetite, ilmenite, clinopyroxene and titanite. Whenever possible, at least 5 analyses per phase were done. 


\subsubsection{Attainment of equilibrium}

The crystallization experiments show textural and compositional features similar to those observed in crystallization experiments conducted on phonolitic compositions (e.g., Freise et al., 2003; Scaillet et al., 2008; Andújar et al., 2008, 2010; Fig. 2b). These features include: (1) a homogeneous distribution of the phases within the charges, (2) euhedral crystals, (3) homogeneous phase compositions, including glass (Fig. 2), and (4) the smooth variation of phase proportions and compositions with changes in experimental conditions. The duration of our experiments (1 to 2 weeks) is within the range of that applied in other studies, including for phonolitic systems (Berndt et al., 2001; Freise et al., 2003; Harms et al., 2004; Scaillet et al., 2008), for which close to equilibrium conditions were also proposed (see also Scaillet and Evans 1999; Costa et al., 2004; Andújar et al., 2008, 2010, and Pichavant et al., 2007).

\section{Experimental results}

\subsection{Phase relations}

The main features of the phase relations are shown in a series of polybaricisothermal (Fig. 4a-c) or isobaric-polythermal (Fig. 4d) sections. At $900^{\circ} \mathrm{C}$ the liquidus phase is biotite at all investigated pressures and melt water content $\left(\mathrm{H}_{2} \mathrm{O}_{\text {melt }}\right)$. Biotite crystallization is followed by the co-crystallization of magnetite plus ilmenite, then alkali feldspar with decreasing $\mathrm{H}_{2} \mathrm{O}_{\text {melt }}$. Clinopyroxene has a narrow stability field and only appears at $\mathrm{H}_{2} \mathrm{O}_{\text {melt }}<2.5 \mathrm{wt} \%$ at $900{ }^{\circ} \mathrm{C}$. At about $850^{\circ} \mathrm{C}$, magnetite and ilmenite become the liquidus phases and biotite co-crystallization occurs at $\mathrm{H}_{2} \mathrm{O}_{\text {melt }}<6$ wt \% (Fig. 4). At $850^{\circ} \mathrm{C}$ the stabilities of alkali feldspar and clinopyroxene increase towards higher $\mathrm{H}_{2} \mathrm{O}_{\text {melt }}$ (between 4 and $5 \mathrm{wt} \%$ ). At $800{ }^{\circ} \mathrm{C}$ major phase changes occur, with cocrystallization of magnetite, clinopyroxene and biotite at liquidus conditions. Alkali feldspar is less affected and still crystallizes for a $\mathrm{H}_{2} \mathrm{O}_{\text {melt }}$ of $5 \mathrm{wt} \%$, similar to conditions at $850^{\circ} \mathrm{C}$. At $800^{\circ} \mathrm{C}$, ilmenite disappears and is replaced by titanite. The stability field of titanite is poorly constrained but the results show that under the T- $f \mathrm{O}_{2}$ conditions explored it only appears at $>150 \mathrm{MPa}$ (Figs. 4c and 4d).

Despite the small $\mathrm{fO}_{2}$ range that we have investigated we find significant changes in phase stabilities with $\mathrm{fO}_{2}$. A decrease from NNO to NNO-0.5 at $850^{\circ} \mathrm{C}$ and $100 \mathrm{MPa}$, increases the clinopyroxene stability to slightly higher $\mathrm{H}_{2} \mathrm{O}_{\text {melt }}$ (from $4 \mathrm{wt} \%$ at $\mathrm{NNO}$ to 
4.6 wt \% at NNO-0.5) and moves the alkali feldspar field towards lower $\mathrm{H}_{2} \mathrm{O}_{\text {melt }}$ (Fig. 4, Table 2).

\subsection{Phase proportions}

Calculated phase proportions show that, as expected, crystallinity increases with decreasing temperature, decreasing $\mathrm{H}_{2} \mathrm{O}_{\text {melt }}$ and increasing pressure (Fig. 4, Table 2). At $900^{\circ} \mathrm{C}$ the crystal content is $<5 \mathrm{wt} \%$ for $\mathrm{H}_{2} \mathrm{O}_{\text {melt }}$ between 6 and $3 \mathrm{wt} \%$, at all studied pressures. For $\mathrm{H}_{2} \mathrm{O}_{\text {melt }}$ of about 1 to $3 \mathrm{wt} \%$ the crystal content increases to $>30 \mathrm{wt} \%$. At $850^{\circ} \mathrm{C}$ and $\mathrm{H}_{2} \mathrm{O}_{\text {melt }}$ in the range $6.5-5 \mathrm{wt} \%$ the crystal contents are $<5 \mathrm{wt} \%$, but crystallinities increase to up to $30 \mathrm{wt} \%$ when $\mathrm{H}_{2} \mathrm{O}_{\text {melt }}$ decreases to about 1 wt\% (between 200 and $100 \mathrm{MPa}$ ). The abrupt and strong increase in crystallinity is enhanced at $50 \mathrm{MPa}$, where small variations in $\mathrm{H}_{2} \mathrm{O}_{\text {melt }}( \pm 0.5 \mathrm{wt} \%)$ increase the crystal content by about $10 \mathrm{wt} \%$. Charges run at $800^{\circ} \mathrm{C}, 200 \mathrm{MPa}$, and close to water saturation conditions have crystal contents of $5 \mathrm{wt} \%$, increasing up to $25 \mathrm{wt} \%$ when $\mathrm{H}_{2} \mathrm{O}_{\text {melt }}$ decreases by only $0.5 \mathrm{wt} \%$. Moreover, at such temperature and for a given $\mathrm{H}_{2} \mathrm{O}_{\text {melt }}$, a decrease in pressure from 200 to $100 \mathrm{MPa}$ increases the crystal content by about $15 \mathrm{wt} \%$. The large changes in crystallinities with varying $\mathrm{H}_{2} \mathrm{O}_{\text {melt }}$ are essentially controlled by the amounts of alkali feldspar, whereas in charges with low crystal content $(<5 \mathrm{wt} \%)$ biotite, magnetite and ilmenite are the main crystallizing phases (Fig. 4, Table 2).

\subsection{Mineral compositions}

\subsubsection{Ilmenite and magnetite}

Ilmenite and magnetite were identified by SEM-EDS but they were often too small for reliable electron microprobe analysis to be performed. We nevertheless analysed $\mathrm{Fe}$-Ti oxides in 7 charges, whose compositions have been corrected out from the glass contribution (less than $3 \%$ of contamination) and the results are shown in Table 4. Magnetite $\mathrm{FeO} *$ and $\mathrm{TiO}_{2}$ contents range between 77-79 wt $\%$, and 17-14 wt $\%$, respectively, with an $\mathrm{Mg} \#$ of 3-4. Ilmenite crystallizing at $850^{\circ} \mathrm{C}$ and at $\mathrm{H}_{2} \mathrm{O}_{\text {melt }} 4-5 \mathrm{wt} \%$ has $\mathrm{TiO}_{2}$ contents in the range 49-51 wt\%, while its $\mathrm{FeO}^{*}$ varies from 45 to $42 \mathrm{wt} \%$, depending on $\mathrm{H}_{2} \mathrm{O}_{\text {melt }}$ (Table 4).

\subsubsection{Biotite}


Experimental biotites have $\mathrm{Mg \#}$ in the range 50-68, and define two populations depending on temperature (Fig. 5; Table 4): those from $900^{\circ} \mathrm{C}$ have higher $\mathrm{Mg \#}$ (> 57) than at $850^{\circ} \mathrm{C}$. At constant pressure and temperature, a decrease in $\mathrm{H}_{2} \mathrm{O}_{\text {melt }}$ decreases $\mathrm{Mg \#}$. For example, at $900^{\circ} \mathrm{C}$ and $50 \mathrm{MPa}$ the $\mathrm{Mg \#}$ decreases from 68 to 63 with a decrease in melt water content of only $0.7 \mathrm{wt} \%$. Similar variations in $\mathrm{Mg \#}$ are observed at $900^{\circ} \mathrm{C}, 100 \mathrm{MPa}$ but, over a wider range of $\mathrm{H}_{2} \mathrm{O}_{\text {melt }}$ (Fig. 5). Otherwise, a decrease of pressure at a constant temperature and $\mathrm{H}_{2} \mathrm{O}_{\text {melt }}$ increases the $\mathrm{Mg} \#$ of biotite.

\subsubsection{Clinopyroxene}

Experimental clinopyroxenes are diopside and hedenbergite according to Morimoto (1989), spanning the range of compositions between $\mathrm{En}_{24} \mathrm{Fs}_{26} \mathrm{Wo}_{47}$ and $\mathrm{En}_{34}$ $\mathrm{Fs}_{19} \mathrm{Wo}_{45}$, with $\mathrm{Mg} \#$ varying between 47 and 64. Clinopyroxene composition is affected by variations in experimental temperature and changes in melt water content (Fig.6).

When temperature increases from 800 to $850^{\circ} \mathrm{C}$, the $\mathrm{Mg \#}$ of clinopyroxene increases from 45 to 55, the En content from 24\% to 29\%, whilst Fs decreases from $27 \%$ to $23 \%$, and Wo remains almost constant. These variations include charges ran at different $\mathrm{P}$ and $f \mathrm{O}_{2}$. At pressures $\geq 100 \mathrm{MPa}$ a variation in $\mathrm{H}_{2} \mathrm{O}_{\text {melt }}$ does not appreciably affect clinopyroxene composition, but in runs at $50 \mathrm{MPa}$, as $\mathrm{H}_{2} \mathrm{O}_{\text {melt }}$ increases, the En and $\mathrm{Mg \#}$ increase while Fs and Wo decrease (Fig. 6). Similar compositional variations were observed in experiments done on other phonolites (e.g., Andújar et al. 2008, 2010) but, their magnitude remain smaller compared to those observed in more silicic compositions (e.g., Scaillet and Evans, 1999).

\subsubsection{Alkali feldspar}

Alkali feldspars are anorthoclase with compositions between $\mathrm{An}_{9} \mathrm{Ab}_{70} \mathrm{Or}_{21}$ and $\mathrm{An}_{2} \mathrm{Ab}_{64} \mathrm{Or}_{34}$, depending essentially on temperature and $\mathrm{H}_{2} \mathrm{O}_{\text {melt }}$. At constant pressure, both $\mathrm{An}$ and $\mathrm{Ab}$ decrease whereas $\mathrm{Or}$ increases with decreasing temperature and $\mathrm{H}_{2} \mathrm{O}_{\text {melt }}$ (Fig. 7). However, the effect of temperature is larger than the effect of $\mathrm{H}_{2} \mathrm{O}_{\text {melt }}$ and the compositional variations are enhanced at lower pressures. For example, at $50 \mathrm{MPa}$ and for a constant $\mathrm{H}_{2} \mathrm{O}_{\text {melt }}$ of $2 \mathrm{wt} \%$, an increase in temperature from $850^{\circ} \mathrm{C}$ to $900^{\circ} \mathrm{C}$ increases the An content of anorthoclase from 2 mole \% to 9 mole\%. In contrast, at 200 $\mathrm{MPa}$ and constant $\mathrm{H}_{2} \mathrm{O}_{\text {melt }}\left(4 \mathrm{wt} \%\right.$ ), a variation in temperature from 850 to $800^{\circ} \mathrm{C}$ does not appreciably affect the composition of alkali feldspar. 


\subsection{Glass}

Residual glass compositions are reported in Table 5. The $\mathrm{Na}_{2} \mathrm{O}+\mathrm{K}_{2} \mathrm{O}$ is between 15 and $18 \mathrm{wt} \%$, and $\mathrm{SiO}_{2}$ contents range between 61.7 and $58.3 \mathrm{wt} \%$ (reported compositions were re-calculated to $100 \%$ anhydrous; Table 5; Fig. 8). According to Le Maitre et al. (1989), all experimental glasses are phonolitic and mildly per-alkaline (molar $\mathrm{Na}+\mathrm{K} / \mathrm{Al}$ between 1.1 and 1.3). The glass composition varies according to changes in intensive parameters and thus with phase proportions. For a given pressure and temperature, $\mathrm{SiO}_{2}$ displays a complex trend of increase and then decrease with decreasing $\mathrm{H}_{2} \mathrm{O}_{\text {melt }}$ (Fig 8a). For a constant temperature, the highest $\mathrm{SiO}_{2}$ enrichment is displaced towards higher $\mathrm{H}_{2} \mathrm{O}_{\text {melt }}$ with increasing pressure, though the effect is more pronounced at $<900^{\circ} \mathrm{C}$ (Fig. 8). The $\mathrm{SiO}_{2}$ variation is controlled by the onset of alkali feldspar crystallization, although the maximum $\mathrm{SiO}_{2}$ enrichment depends also on the relative abundances of oxides and biotite (Table 2). Glasses from charges at $200 \mathrm{MPa}$ and $900^{\circ} \mathrm{C}$ with biotite present have slightly lower $\mathrm{SiO}_{2}(60.5 \mathrm{wt} \%)$ than at $850^{\circ} \mathrm{C}(61.5$ wt\%), where magnetite-ilmenite prevail over biotite (Figs.4 and 8). At a given $\mathrm{H}_{2} \mathrm{O}_{\text {melt }}$, the $\mathrm{SiO}_{2}$ content increases by about $0.5-1 \mathrm{wt} \%$ with an increase of $50^{\circ} \mathrm{C}$ and of $50 \mathrm{MPa}$.

A decrease in temperature of $50^{\circ} \mathrm{C}$ at a given pressure and $\mathrm{H}_{2} \mathrm{O}_{\text {melt }}$, leads to a decrease of $\mathrm{TiO}_{2}, \mathrm{MgO}$ and $\mathrm{CaO}$ contents by about $50 \%$ relative, whereas both $\mathrm{Na}_{2} \mathrm{O}$ and $\mathrm{K}_{2} \mathrm{O}$ slightly increase. A decrease in pressure leads to an increase in $\mathrm{MgO}$ and a decrease in $\mathrm{CaO}$ contents. However, at $50 \mathrm{MPa}$, compositional changes with intensive variables are different from those observed at higher pressures. Residual glasses at $900^{\circ} \mathrm{C}$ have higher $\mathrm{MgO}$ contents than at $850^{\circ} \mathrm{C}$. Moreover, a decrease in $\mathrm{H}_{2} \mathrm{O}_{\text {melt }}$ increases the $\mathrm{MgO}$ content of the glass. Such compositional variations have been also documented in other experiments performed on similar compositions at low pressure (e.g., Andújar and Scaillet, 2012a). The effect of $f \mathrm{O}_{2}$ on glass compositions is small, reflecting the limited range of $\mathrm{fO}_{2}$ investigated. However, experiments conducted at more reducing conditions (NNO-2) yield glasses with lower $\mathrm{TiO}_{2}, \mathrm{MgO}$ and $\mathrm{CaO}$ and higher $\mathrm{SiO}_{2}, \mathrm{Al}_{2} \mathrm{O}_{3}$ and $\mathrm{K}_{2} \mathrm{O}$ contents than those synthesised at NNO.

\section{Discussion}

6.1. Natural versus experimental data: constraints on the pre-eruptive conditions of Roques Blancos 
The comparison between the mineral assemblage of the natural phonolite (14 wt $\%$ of phenocrysts, mainly alkali feldspar, but also clinopyroxene, biotite and Fe-Ti oxides) and those from experiments provides first-order constraints on the magma preeruptive conditions. At temperatures between 850 and $900^{\circ} \mathrm{C}$ the crystal content and phase assemblage of the natural phonolite have been reproduced at pressures between 75 and $25 \mathrm{MPa}$, and $\mathrm{H}_{2} \mathrm{O}_{\text {melt }}$ 2.0-4.0 wt\% (Fig. 4). Lower temperatures (e.g. $800{ }^{\circ} \mathrm{C}$ ) can be ruled out because of the much higher crystal content and absence of ilmenite in the explored ranges of $\mathrm{H}_{2} \mathrm{O}_{\text {melt }}$ and pressures. Pressures higher than about $75 \mathrm{MPa}$ can also be ruled out because clinopyroxene only occurs at crystal contents higher than in the natural phonolite. We have not performed experiments at $<50 \mathrm{MPa}$, but extrapolation of the crystallinity and phase equilibrium relationships obtained at $50 \mathrm{MPa}$ also suggests much higher crystallinities at pressures significantly lower than $50 \mathrm{MPa}$. To refine and test the robustness of such constraints we use below the compositions of mineral and glass.

Natural magnetite has a $\mathrm{Mg \#}$ of 5 whereas our two experimental magnetites from experiments conducted at $850^{\circ} \mathrm{C}, 100$ and $50 \mathrm{MPa}$, and $\mathrm{H}_{2} \mathrm{O}_{\text {melt }}$ of about 3 wt\% have $\mathrm{Mg \#}$ of 3 to 4 . Magnetite composition varies with temperature and $\mathrm{fO}_{2}$ (e.g, Andújar et al. 2008, 2010) and thus, the slightly higher Mg\# of the natural magnetite suggests higher temperatures (e.g., $>850^{\circ} \mathrm{C}$ ) or/and more oxidizing conditions (e.g., $f \mathrm{O}_{2}$ $>\mathrm{NNO}$ ). We have reproduced the $\mathrm{TiO}_{2}$ content of the natural ilmenite at $850^{\circ} \mathrm{C}, 200$ $\mathrm{MPa}$ and $\mathrm{H}_{2} \mathrm{O}_{\text {melt }}$ of $5.5 \mathrm{wt} \%$, although these conditions are different from those inferred above.

Experimental biotites crystallizing between 50 and $200 \mathrm{MPa}$ at $900^{\circ} \mathrm{C}$, and $\mathrm{H}_{2} \mathrm{O}_{\text {melt }}$ between 1.5-4.5 wt\% encompass the Mg\# of natural biotites (Mg\# 63, Fig. 5). However, at this temperature only experiments performed at $50 \mathrm{MPa}$ and $\mathrm{H}_{2} \mathrm{O}_{\text {melt }}<2.5$ wt $\%$ reproduce the phase assemblage and crystal content of the natural phonolite. At $850^{\circ} \mathrm{C}$ the experimental biotites have lower $\mathrm{Mg} \#$ than those from the phonolite.

We have successfully reproduced the rim and core compositions of the natural alkali feldspars. Their Ca-rich rims $\left(\mathrm{An}_{7-8}\right)$ are reproduced at $900^{\circ} \mathrm{C}, 50 \mathrm{MPa}$ and $\mathrm{H}_{2} \mathrm{O}_{\text {melt }}$ $\sim 2 \mathrm{wt} \%$ while cores (the bulk of crystals, see Fig 3), which range from $\mathrm{An}_{2.5}$ to $\mathrm{An}_{4}$, are reproduced at $850^{\circ} \mathrm{C}, 50 \mathrm{MPa}$ and $\mathrm{H}_{2} \mathrm{O}_{\text {melt }}$ between 2-3 wt\% (Fig. 7). These results support our pressure estimate of $50 \mathrm{MPa}$ for the storage conditions prior to eruption but indicate also that crystallization of natural feldspars occurred at two different conditions: the Ca-poor cores crystallized at $850^{\circ} \mathrm{C}$, whilst the Ca-rich rim crystallized 
at $900^{\circ} \mathrm{C}$. Such a temperature difference suggests a change in the storage temperature of the reservoir just prior to eruption which, as we show below, is also consistent with biotite and $\mathrm{Fe}$-Ti oxide reequilibration.

We have not obtained EMP analyses of clinopyroxene in charges produced at $900^{\circ} \mathrm{C}$ due to the small size of crystals; however, the compositional trends displayed by the experimental clinopyroxenes support this temperature for natural clinopyroxene crystallization. At $850^{\circ} \mathrm{C}, 50 \mathrm{MPa}$ and $\mathrm{H}_{2} \mathrm{O}_{\text {melt }}$ of $2 \mathrm{wt} \%$, both the $\mathrm{Mg} \#$ and En content of natural clinopyroxene are closely reproduced yet, Fs and Wo are slightly different. However, an increase of temperature of $50^{\circ} \mathrm{C}$ will produce a $5 \%$ moles increase in the En content and $\mathrm{Mg \#}$ of clinopyroxenes but also, a 5\% moles decrease in the Fs content, producing a clinopyroxene similar to the natural one (Fig.6; see previous section).

The comparison between natural and experimental phase relationships and mineral compositions therefore suggests pre-eruptive conditions for the Roques Blancos phonolite to be $850-900^{\circ} \mathrm{C}, 50 \mathrm{MPa}$, and melt water contents between 2 to $2.5 \mathrm{wt} \%$ $\left(\mathrm{P}_{\text {total }}<\mathrm{PH}_{2} \mathrm{O}\right)$. At such conditions the $\mathrm{SiO}_{2}, \mathrm{CaO}, \mathrm{Na}_{2} \mathrm{O}, \mathrm{MgO}, \mathrm{TiO}_{2}$ and $\mathrm{K}_{2} \mathrm{O}$ contents of the residual melt are closely reproduced (Table 1; Fig. 8). Only $\mathrm{FeO}^{*}$ and $\mathrm{Al}_{2} \mathrm{O}_{3}$ contents are different (but almost within error if analytical uncertainties are considered) than those from experiments conducted at $850-900^{\circ} \mathrm{C}$ and $50 \mathrm{MPa}$ (Fig. 8).

We do not have enough experimental data from different $\mathrm{fO}_{2}$ (i.e., biotite, $\mathrm{Fe}-\mathrm{Ti}$ oxides) to make a precise determination of the pre-eruptive oxygen fugacity. However, the fact that we have successfully reproduced the phase assemblage, crystal content and phase compositions of the natural phonolite at an $f \mathrm{O}_{2} \sim \mathrm{NNO}$ suggests that such an $\mathrm{fO}_{2}$ broadly prevailed in the reservoir. Moreover, the $\mathrm{Mg \#}$ of the natural biotite (which is highly sensitive to $\left.f \mathrm{O}_{2}\right)$ is reproduced at an $f \mathrm{O}_{2} \sim \mathrm{NNO}-1$; hence a pre-eruptive $f \mathrm{O}_{2}$ between NNO and NNO-1 appears to be a good redox estimate for the natural phonolite, in accord with constraints obtained from natural magnetite-ilmenite pairs (Table 1) and with those obtained previously for other phonolites from Tenerife (Ablay et al., 1998; Andújar et al., 2008, 2010; Andújar and Scaillet, 2012a). On the basis of the foregoing discussion we conclude that prior to eruption the Roques Blancos phonolite was stored at $50 \pm 15 \mathrm{MPa}, 875^{\circ} \mathrm{C} \pm 25^{\circ} \mathrm{C}$, with $\mathrm{H}_{2} \mathrm{O}_{\text {melt }} 2-2.5 \mathrm{wt} \%$, at an $f \mathrm{O}_{2}$ of NNO0.5 ( \pm 0.5$)$. Although the pre-eruptive $\mathrm{H}_{2} \mathrm{O}_{\text {melt }}$ is rather low, the low pressure of magma storage implies that any coexisting fluid phase in the reservoir will be dominated by $\mathrm{H}_{2} \mathrm{O}$ (ie $\mathrm{XH}_{2} \mathrm{O}>0.5$ ). Evidence for dissolved pre-eruptive $\mathrm{CO}_{2}$ is generally lacking in phonolite magmas (e.g., Andujar and Scaillet, 2012a,b), including at Tenerife, which 
shows that, if present, $\mathrm{CO}_{2}$ must reside primarily in the vapor phase, albeit in moderate amounts to be compatible with our inferred $\mathrm{H}_{2} \mathrm{O}_{\text {melt }}$.

\subsection{Evidence for late magma reheating upon mixing before eruption}

Many Roques Blancos alkali feldspars are characterised by a reverse compositional zoning with An-rich rims and Or-poor cores (Fig. 3). We have successfully reproduced such An-rich compositions at $900^{\circ} \mathrm{C}, 50 \mathrm{MPa}, 2 \mathrm{wt} \% \mathrm{H}_{2} \mathrm{O}_{\text {melt }}$ whereas cores are reproduced at the same pressure and $\mathrm{H}_{2} \mathrm{O}_{\text {melt }}$ but at a lower $\mathrm{T}, 850^{\circ} \mathrm{C}$ (Figs. 4 and 7). Reverse zoning in feldspars are generally interpreted as arising from crystallisation of a more $\mathrm{Ca}$-rich melt, often related to mixing with a more mafic magma (e.g., Couch et al. 2001, Martel et al, 2006). Alternatively, experimental works have shown that such $\mathrm{Ca}$-rich rims can be also produced by increasing temperature without interaction with a mafic body (e.g., Rutherford et al., 1985; Couch et al., 2001), by increasing pressure at water-saturated conditions (Rutherford and Devine 2008), or by an increase in water activity via the preferential loss of a $\mathrm{CO}_{2}$ (Holloway, 1976). To discriminate between the different possibilities, it is useful to compare changes in An content with changes in other minor elements as shown by Triebold et al. (2006) and Ruprecht and Wörner (2007). These authors suggest that a process of magma mixing can be identified in feldspars when the An enrichment is accompanied by an increase in Fe content whereas when Fe remains constant, only an increase in temperature can explain the Ca-rich compositions. The compositional traverses show that the increase in the An content towards the rims of the crystals is indeed coupled with an increase in the $\mathrm{FeO} *, \mathrm{TiO}_{2}$ and $\mathrm{BaO}$ which suggests that such $\mathrm{Ca}$-rich rims record the income of a more mafic and higher temperature melt, as proposed by Triebold et al. (2006) and Ruprecht and Wörner (2007). This hypothesis is also supported by our experimental results: the observed $\mathrm{CaO}-\mathrm{FeO}^{*}-\mathrm{TiO}_{2}$ enrichment of the alkali feldspar rims cannot be explained only by a single shift in temperature or water activity because in each case, the stability field, phase proportions and composition of phases like biotite, magnetite, or clinopyroxene will be also modified. In detail, at $900^{\circ} \mathrm{C}$ for reproducing the low $\mathrm{Ca}-$ cores of feldspars, crystal contents $>30 \mathrm{wt} \%$ and $\mathrm{H}_{2} \mathrm{O}_{\text {melt }}<1.7 \mathrm{wt} \%$ are required (fig. 4). Then, to generate the $\mathrm{An}_{7-8}$ rims, $\mathrm{H}_{2} \mathrm{O}_{\text {melt }}$ should increase to $2.5 \mathrm{wt} \%$ and the crystal content should be reduced by $\sim 50 \%$ to achieve the $14 \mathrm{wt} \%$ phenocryst of the phonolite (Fig. 4). The presence of resorbed textures in feldspars cores and clinopyroxenes (Fig. 3 ) is compatible with such an hypothesis; however, although the rise in temperature or 
$\mathrm{H}_{2} \mathrm{O}_{\text {melt }}$ will increase the Ca content of the coexisting melt, producing a shift in the An content, it will keep $\mathrm{FeO}^{*}$ and $\mathrm{TiO}_{2}$ concentrations constant, a trend unlike the rimward enrichment in these elements observed in natural feldspars (Fig. 8). The above lines of evidence thus suggest that the most likely mechanism for explaining the compositional zonation of alkali feldspars is mixing with a hotter and more mafic magma. In such a scenario, the observation that only biotite and $\mathrm{Fe}-\mathrm{Ti}$ oxides compositions record the conditions following the intrusion of the more mafic and hotter melt can be explained by their much faster kinetics of intracrystalline diffusion compared to other minerals (e.g., Cherniak and Dimanov, 2010; Van Orman and Crispin, 2010). Although we do not have detailed compositional zoning in clinopyroxene to further check this hypothesis, the BSE images show multiple growth zones with dissolution surfaces, which is consistent with an open-system evolution with abrupt changes in temperature and composition.

Magma mixing and mingling are common processes occurring at Tenerife, as recorded by the existence of mingled-mixed products or by reversely zoned phenocrysts (Araña et al., 1994; Ablay et al., 1998; Neumann et al., 1999, Triebold et al, 2006), as discussed above. The steep increase in $\mathrm{Ba}$ recorded in the alkali feldspars (Fig. 3) provides insights into the composition of the mafic end-member. According to Ablay et al. (1998), among the mafic magmas erupted in the last $30 \mathrm{kyr}$, tephriphonolites are the most Ba-enriched, in particular those erupted from Pico Viejo vent, which can contain up to $1400 \mathrm{ppm}$ of $\mathrm{Ba}$. Estimated pre-eruptive temperatures of such tephriphonolites are in the range $1020-1040^{\circ} \mathrm{C}$ (Ablay et al., 1998; Neumann et al., 1999), hence they are hot enough to increase temperature, at least locally, yielding Ca-rich overgrowth on alkali feldspars of the Roques Blancos phonolite when entering in the reservoir, although in detail the thermal effects will depend on the relative masses of juxtaposed magmas.

According to these observations, the following sequence of events for the late magmatic evolution of the Roques Blancos magma reservoir prior to the eruption can be proposed. The phonolite was ponding at depths between 1-2 $\mathrm{km}$ and at temperatures around $850^{\circ} \mathrm{C}$, where the bulk of crystallization of the alkali feldspars occurred yielding the $\mathrm{Ca}$ and $\mathrm{Ba}$ poor cores. Intrusion of a hotter tephriphonolitic melt into the more evolved magma increased the temperature of the resident phonolite and enriched the residual melt in $\mathrm{Ca}, \mathrm{Ti}, \mathrm{Fe}$ and $\mathrm{Ba}$ from which the outer rims of feldspar crystallized, while biotite and Fe-Ti oxides quickly re-equilibrated. The arrival of this hotter and 
more mafic intrusion might have triggered the eruption some time later (e.g., Folch and Martí, 1998).

\subsection{Central versus flank eruptions in Tenerife and their relation to different eruptive styles}

The volcanic activity of the last $30 \mathrm{kyr}$ of the Teide-Pico Viejo complex is characterised by the eruption of intermediate to phonolitic magmas which volumetrically predominated over the basaltic ones (Ablay et al., 1998; Carracedo et al., 2007, Martí et al., 2008). The phonolitic eruptions alternate between central Pico Teide and Pico Viejo vents and several flank domes located around the stratovolcanoes, with these last dominating the evolution of the actual volcanic system in terms of number of events (Ablay and Martí, 2000; Carracedo and Rodríguez-Badiola, 2006; RodríguezBadiola et al., 2006; Carracedo et al., 2007). Flank dome eruptions share several physical, petrographic, geochemical, and volcanological features. Phonolitic domes are located at heights between 2000 and $3000 \mathrm{~m}$ a.s.l. over the steep flanks of the TeidePico Viejo stratovolcanoes: generally they are volumetrically smaller than eruptions occurring from the central vents (Ablay, 1997; Martí et al., 2008; Carracedo et al., 2007; Martí et al., 2012) and are characterised by the emission of thick phonolitic lava flows. They typically have also an explosive phase that produces significant fall-out deposits, as documented for the eruptions of Montaña Blanca and El Boquerón (Ablay et al. 1995; Andújar and Scaillet, 2012a; García et al., 2012)

Previous estimates of the storage conditions of flank dome eruptions in Tenerife were done using thermo-barometric models (Ablay, 1997; Ablay et al., 1995; Ablay et al., 1998). Coexisting Fe-Ti oxides of Arenas Blancas, Montaña Las Lajas, and Montaña Blanca flank eruptions yield temperatures in the range $775-900^{\circ} \mathrm{C}$ (Ablay, 1997; Ablay et al., 1995; Ablay et al., 1998). These authors also measured water contents of melt inclusions trapped in clinopyroxenes from Montaña Majua and Montaña Blanca flank dome eruptions, reporting values of $1.2-2.5 \mathrm{wt} \%$, and $3-4.5 \mathrm{wt} \%$, respectively. Using the volatile content and the water solubility model of Carroll and Blank (1997), Ablay et al. (1995) inferred a storage pressure of $100 \mathrm{MPa}$ for the Montaña Blanca eruption. New experimental results by Andújar and Scaillet (2012a) using the products of the subplinian phase of the Montaña Blanca eruption suggest instead that this magma was stored at $850 \pm 15^{\circ} \mathrm{C}, 50 \pm 15 \mathrm{MPa}, 2.5 \pm 0.5 \mathrm{wt} \% \mathrm{H}_{2} \mathrm{O}_{\text {melt }}$. This phase of the eruption involved the emission of a crystal-poor phonolitic magma (1 to $4 \mathrm{wt} \%$ of phenocrysts) 
with a composition similar to that of Roques Blancos. We have calculated the magma viscosities of these two phonolites (models of Giordano et al., 2008, and Scaillet et al. 1998; Andújar and Scaillet, 2012b) and have found about the same values (10 $\left.{ }^{4.1} \mathrm{~Pa}^{*} \mathrm{~s}\right)$. This and their similar storage conditions, which are close to water-saturation according to available $\mathrm{H}_{2} \mathrm{O}$-solubility models in phonolitic melts (Carroll and Blank, 1997; Schmidt and Behrens, 2008), indicate that both magmas would respond similarly upon decompression. The explosive nature of the Montaña Blanca eruption suggests that it is

likely that the beginning of the Roques Blancos eruption had a short-lived highly explosive initial phase, which is in agreement with the recent identification of fall-out deposits associated with this eruption (O. García unpublished data).

The physical and petrological features shared between the most recent satellite phonolitic eruptions of Teide-Pico Viejo (Fig. 1) and that of Montaña Blanca, El Boquerón and Roques Blancos, all point towards a shallow origin for these flank eruptions, which appear to have been fed by reservoirs located at depths of 1-2 km below the surface. These shallow values contrast with those experimentally determined for central eruptions occurring from Teide proper, which were constrained to be about 5 $\mathrm{km}$ below the actual summit of Pico Teide volcano (Andújar et al., 2010). In figure 9 we have projected the depths for the Roques Blancos, Montaña Blanca and central Teide phonolitic magmas. It shows that phonolitic magmas can be stored at various depths in Tenerife, up to very close to the surface ( 1-2 km below the surface), suggesting that the phonolite storage region of Teide is not characterised by one single and large reservoir, but instead by various isolated, possibly transient, magma pockets that can coexist simultaneously, re-enforcing and supporting previous observations obtained from petrological data and modelling efforts (Ablay et al., 1998; Andújar and Scaillet, 2012a; Martí and Geyer, 2009). The characteristics of the actual plumbing system beneath Teide-Pico Viejo where several phonolitic shallow reservoirs can co-exist, as well as the difference in storage depths, can thus explain the multiple shifts between central and lateral eruptions documented to occur at this stratovolcano (Martí and Geyer, 2009).

\section{Conclusions}

Crystallization experiments on a phonolitic product of the Roques Blancos eruption, a representative flank eruption of the large Teide stratovolcano, show that it was stored at shallow depths (about $50 \mathrm{MPa}$ or 1-2 $\mathrm{km}$ ) below the edifice with about 2.5 wt $\%$ water dissolved in the melt. The main petrological features (crystal content, phase 
assemblage, phase compositions) of the natural phonolite are reproduced at $900^{\circ} \mathrm{C}$, though the composition of Ca-poor cores of alkali feldspar record lower temperatures of about $850^{\circ} \mathrm{C}$. The zoning pattern of natural alkali feldspars show that they have high $\mathrm{Ba}$, $\mathrm{Ti}$, and Fe rims which, we suggest, record a late and transient reheating following mixing of the resident magma with a more mafic melt. Such shallow and water-rich storage conditions were also determined for another flank and Plinian eruption of Teide and contrast with the deeper reservoir inferred for predominantly effusive eruptions of magmas emitted from the central Teide cone. Such differences in storage depths and locations illustrate the complexity of the magma plumbing system that may currently exist below Teide, which does not appear to be fed from a single large reservoir. Instead, the evidence call for multiple isolated small magma reservoirs, whose level of assembly in upper crust is in part controlled by the feedback existing between the evolution and growth of the aerial cone built/destroyed during eruptions and the local stress field at depth.

The results from the current work should help improve hazard assessment at Tenerife, along with the forecasting the future behaviour of phonolitic magmas stored below Teide-Pico Viejo volcanic system. In particular, the new constraints we provide about both pre-eruptive $\mathrm{H}_{2} \mathrm{O}_{\text {melt }}$ of phonolites and their storage depths may help in providing a first estimate of the explosive/effusive potential of these magmas by using the location of tremors during an on-going eruption at central parts of the island. Nevertheless, we stress that the explosive vs non-explosive character of alkali-rich magmas can be easily changed by additional factors (ie, influx of other volatile species like $\mathrm{CO}_{2}$, degassing, interaction with meteoric water, mixing with mafic compositions within the conduit); and will be always subordinated to the composition of the ascending magma, which is so far virtually impossible to know with the available monitoring tools.

\section{Acknowledgements}

J.A. thanks M. Pompilio and A. Burgisser for their scientific discussions that improved previous versions of the manuscript. L. Ramon, O. Rouer and I. Di Carlo are thanked for their technical support. Comments from J.M. Castro greatly helped to improve the manuscript. This work was funded by "Beatriu de Pinós" fellowship BPA-00072 and a fellowship grant from the University of Orléans. Joan Martí is thanked by providing the 
logistical support during rock sampling at Tenerife, as well as for the comments and editorial handling of the paper.

\section{References}

Ablay, G. J., Ernst, G. G. J., Martí, J., Sparks, R.S.J, 1995. The 2ka subplinian eruption of Montaña Blanca, Tenerife. Bull. Volcanol. 57, 337-355.

Ablay, G. J., 1997. Evolution of the Teide-Pico Viejo volcanic complex and magmatic system (Tenerife, Canary Islands). Department of Geology. Bristol, University of Bristol. 336 pp.

Ablay, G. J., Carroll, M.R., Palmer, M.R., Martí, J., Sparks, R.S.J., 1998. BasanitePhonolite Lineages of the Teide-Pico Viejo Volcanic Complex, Tenerife, Canary Islands. J. Petrol. 39, 905-936.

Ablay, G. J., Martí, J., 2000. Stratigraphy, structure, and volcanic evolution of the Pico Teide-Pico Viejo formation, Tenerife, Canary Islands. J. Volcanol. Geotherm. Res. $103,175-208$.

Andújar, J., Costa, F., Martí, J., Wolff, J.A., Caroll, M.R., 2008. Experimental constraints on pre-eruptive conditions of phonolitic magma from the caldera-forming El Abrigo eruption, Tenerife (Canary islands). Chem. Geol. 257, 173-191

Andújar, J., Costa, F., Martí, J., 2010. Magma storage conditions of the last eruption of Teide volcano (Canary Islands, Spain). Bull. Volcanol. 72, 381-395.

Andújar, J., Scaillet, B., 2012a. Experimental constraints on parameters controlling the difference in the eruptive dynamic of phonolitic magmas: the case from Tenerife (Canary Islands). J. Petrol. http://dx.doi.org/10.1093/petrology/EGS033

Andújar, J., Scaillet, B., 2012b. Relationships between pre-eruptive conditions and eruptive styles of phonolite-trachyte magmas. Lithos 152, 122-131.

Araña, V., 1971. Litología y estructura del Edificio Cañadas, Tenerife (Islas Canarias). Estudios Geologicos 27, 95-135.

Araña, V., Martí, J., Aparicio, A., García-Cacho, L., Carcía-García, R., 1994. Magma mixing in alkaline magmas: An example from Tenerife, Canary Islands, Lithos 32, 119. 
Balcells, R., Hernández-Pacheco, A., 1989. El domo-colada de Roques Blancos. In: Araña, V. and Coello, J. (eds) Los volcanes y la caldera del Parque Nacional del Teide (Tenerife, Islas Canarias). Madrid: ICONA, pp. 235-253.

Berndt, J., Holtz, F., Koepke, J., 2001. Experimental constraints on storage conditions in the chemically zoned phonolitic magma chamber of the Laacher See volcano. Contrib. Mineral. Petrol. 140,469-486.

Bonaccorso, A., Calvari, S., Coltelli, M., Del Negro, C., and Falsaperla, S. (Eds.), 2004. Mt. Etna: Volcano Laboratory, Geophysical Monograph series vol. 143, 369 PP., ISSN: 0065-8448; ISBN: 0-87590-408-4.

Burnham, C. W., Holloway, J. R., Davis, N. F., 1969. Thermo-dynamic properties of water to $1000^{\circ} \mathrm{C}$ and 10000 bar. Geol. Soc. Amer. Spec. Pap. 132, 1-96.

Carracedo, J. C., Rodríguez-Badiola, E., 2006. Los domos y domos-colada del complejo volcanico del Teide. In: Carracedo, J. C. (ed.) Los volcanes del parque nacional del Teide. Madrid: serie técnica Organización de Parques Nacionales, Ministerio de Medio Ambiente, pp. 213-238.

Carracedo, J.C., Rodríguez-Badiola, E., Guillou, H., Paterne, M., Scaillet, S., PérezTorrado, F. J., Paris, R., Fra-Paelo, U., Hansen, A., 2007. Eruptive and structural history of Teide volcano and rift zones of Tenerife, Canary Islands. Geol. Soc. Am. Bull. 119, 1027-1051.

Carroll, M. R., Blank, J.G., 1997. The solubility of $\mathrm{H}_{2} \mathrm{O}$ in phonolitic melts. Am. Mineral. 82, 549-556.

Cherniak, D. J., Dimanov, A., 2010. Diffusion in Pyroxene, Mica and Amphibole Rev. Mineral. Geochem. 72, 641-690.

Corsaro, R.A., Miraglia, L., Pompilio, M., 2007. Petrologic evidence of a complex plumbing system feeding the July-August 2001 eruption of Mt. Etna, Sicily, Italy. Bulletin of Volcanology 69, 401-421.

Costa, F., Scaillet, B., Pichavant, M., 2004. Petrological and experimental constraints on the Pre-eruption conditions of Holocene dacite from Volcán San Pedro $\left(36^{\circ} \mathrm{S}\right.$, Chilean Andes) and the im portance of sulphur in silicic subduction-related magmas. J. Petrol. 45, 855-881.

Couch, S., Sparks, R.S.J., Carroll, M.R., 2001. Mineral disequilibrium in lavas explained by convective self-mixing in open magma chamber. Nature 441,10371039. 
Deer, W.A.; Howie, R.A., Zussman, J., 1972. Rock forming minerals: Framework silicates 4, $435 \mathrm{pp}$.

Di Carlo, I., Pichavant, M., Rotolo, S.G., Scaillet, B., 2006. Experimental crystallization of a High-K arc basalt: the golden pumice, Stromboli volcano (Italy). J. Petrol. 47, $1317-1343$

Freise, M., Holtz, F., Nowak, M., Scoates J.S., Strauss, H., 2009. Differentiation and crystallization conditions of basalts from the Kerguelen large igneous province: an experimental study . Contrib. Mineral. Petrol. 158, 505-527.

Freise, M., Holtz, F., Koepke, J., Scoates, J., Leyrit, H., 2003. Experimental constraints on the storage conditions of phonolites from kerguelen Archipielago. Contrib. Mineral. Petrol. 145, 659-672.

Folch, A., Martí, J., 1999. The generation of overpressure in felsic magma chambers by replenishment. Earth Planet. Sci. Lett. 163, 301-314.

García, O., Bonadonna, C., Martí, J., Pioli, L., 2012. The 5,660 yr BP boquerón explosive eruption, Teide-Pico Viejo complex, Tenerife. Bull. Volcanol. DOI. $10.1007 / \mathrm{s} 00445-012-0646-5$

Harms, E., Gardner., J.E., Schmincke, H.U., 2004. Phase equilibria of the lower Laacher See Tephra (East Eifel, Germany): constrainsts on pre-eruptive storage conditions of a phonolitic magma reservoir. J. Volcanol. Geotherm. Res. 134, 135-148.

Holloway, J.R., 1976. Fluids in the evolution of granitic magmas: consequences of finite $\mathrm{CO}_{2}$ solubility. Geol. Soc. Am. Bull. 87, 1513-1518.

Kahl, M., Chakraborty, S., Costa, F, Pompilio, M., 2011. Dynamic plumbing system beneath volcanoes revealed by kinetic modeling, and the connection to monitoring data: An example from Mt. Etna. Earth. Planet. Sci. Lett. 308, 11-22.

Le Maitre, R.W., Bateman, P., Dudek, A., Keller, J., La Meyre Le Bas, M.J., Sabine, P.A., Schmid, R., Sorensen, H., Streckeisen, A., Wooley, A.R., Zanettin, B., 1989. A classification of igneous rocks and glossary of terms. Blackwell Scientific Publications, 193 pp. Oxford.

Martel, C., Pichavant, M., Holtz, F., Scaillet, B., 1999. Effects of $f \mathrm{O}_{2}$ and $\mathrm{H}_{2} \mathrm{O}$ on andesite phase relations between 2 and 4 kbar. J. Geophys. Res. 104, 29,453-29,470.

Martel, C., Ali, A.R., Poussineau, S., Gourgaud, A., Pichavant, M., 2006. Basaltinherited microlites in silicic magmas: Evidence from Mount Pelée (Martinique, French West Indies). Geology 34, 905-908. 
Martí J., Mitjavila J., Araña, V., 1994. Stratigraphy, structure and geochronology of the Las Cañadas caldera (Tenerife, Canary Island). Geol. Mag. 131,715-727.

Martí, J., Gudmundsson, A., 2000. The Las Cañadas caldera (Tenerife, Canary Islands): an overlapping collapse caldera generated by magma-chamber migration. J. Volcanol. Geotherm. Res. 103, 161-173.

Martí, J., Geyer, A., Andújar, J., Teixidó, F., Costa, F., 2008. Assessing the potential for future explosive activity from Teide-Pico Viejo. J. Volcanol. Geotherm. Res. 178, $529-542$.

Martí, J., Geyer, A., 2009. Central vs flank eruptions at Teide-Pico Viejo twin stratovolcanoes (Tenerife, Canary Islands). J. Volcanol. Geotherm. Res. 181, 47-60.

Martí, J., Sobradelo, S., Felpeto, A., García, O., 2012. Eruptive scenarios of phonolitic volcanism at Teide-Pico Viejo volcanic complex (Tenerife, Canary Islands). Bull. Volcanol. 74, 767-782.

Morimoto, N., 1989. Nomenclature of pyroxenes. Subcomitee on pyroxenes. Commission on new minerals and mineral names. Can. Mineral. 27, 143-156.

Neumann, E.-R., Wulff-Pedersen, E., Simonsen, S.L., Pearson, N.J., Martí, J., Mitjavila, J., 1999. Evidence for fractional crystallization of periodically refilled magma chambers in Tenerife, Canary Islands. J. Petrol. 40, 1089-1123.

Papale P, Moretti R, Barbato, D., 2006 The compositional dependence of the saturation surface of $\mathrm{H}_{2} \mathrm{O}+\mathrm{CO}_{2}$ fluids in silicate melts. Chem. Geol. 229, 78-95.

Pichavant, M., Costa, F., Burgisser, A., Scaillet, B., Martel, C , Poussineau, S., 2007. Equilibration scales in silicic to intermediate magmas - Implications for phase equilibrium studies. J. Petrol. 48, 1955-1972

Pownceby, M.I., O’Neill, H. St.C., 1994. Thermodynamic data redox reactions at high temperatures.III. Activity-composition relations in Ni-Pd alloys from EMF measurements at $850-1250 \mathrm{~K}$ and calibration of the $\mathrm{NiO}+\mathrm{Ni}-\mathrm{Pd}$ assemblage a redox sensor. Contrib. Mineral. Petrol. 116, 327-339.

Robie, R.A., Hemingway, B.S., Fisher, J.R., 1979. Thermodynamic properties of minerals and related substances at $298.15 \mathrm{~K}$ and 1 bar $\left(10^{5}\right.$ pascals $)$ pressure and at higher temperatures. U.S. Geol. Surv. Bull. 1452, 456.

Rodríguez Badiola, E., Pérez Torrado, F.J., Carracedo, J.C., Guillou, H., 2006. Petrografía y geoquímica del edificio volcánico Teide-Pico Viejo y las dorsales 
noreste y noroeste de Tenerife, in Carracedo, J.C., ed., Los Volcanes del Parque Nacional del Teide: Madrid,Serie Técnica. Publicacion Organismo Autónomo Parques Nacionales, Ministerio de Medio Ambiente, p. 129-188.

Ruprecht, P. , Wörner, G., 2007. Variable regimes in magma systems documented in plagioclase zoning patterns: El Misti stratovolcano and Andahua monogenetic cones. J. Volcanol. Geotherm. Res. 165, 142-162.

Rutherford, M.J., Sigurdson, H., Carey, S., Davis, A., 1985. The May 18, 1980, eruption of mount St. Helens 1. melts composition and experimental phase equilibria. J. Geophys. Res. 90, 2929-2947.

Rutherford, M.J., Devine, J.D. III, 2008. Magmatic conditions and processes in the storage zone of the 2004-2006 Mount St. Helens dacite. In: A volcano Rekindled: the renewed eruption of Mount St. Helens 2004-2006.Sherrod, D.R., Scott, W.E., Stauffer, P.H. (eds). U.S. Geol Surv. Prof Paper pp.17-50.

Sauerzapf, U., Lattard, D., Burchard, M., Engelmann, R., 2008. The titanomagnetiteilmenite equilibrium: New experimental data and thermo-oxybarometric application to the crystallization of basic to intermediate rocks. J. Petrol. 49, 1161-1185.

Scaillet, B., Pichavant, M., Roux, J., Humbert, G., Lefevre, A. (1992).

Scaillet, B., Pichavant, M., Roux, J., 1995. Experimental crystallization of leucogranites magmas. J. Petrol. 36, 663-705.

Scaillet, B., Holtz, F., Pichavant, M., 1998. Phase equilibrium constraints on the viscosity of silicic magmas 1 . Volcanic-plutonic comparison. J. Geophys. Res. 103, 27,257-27,266.

Scaillet, B., Evans, B.W., 1999. The 15 June 1991 eruption of Mount Pinatubo. I. phase equilibria and Pre-eruption P-T- $f \mathrm{O}_{2}-\mathrm{aH}_{2} \mathrm{O}$. J. Petrol. 40, 381-411.

Scaillet, B., Pichavant, M., Cioni, R., 2008. Upward migration of Vesuvius magma chamber over the past 20,000 years. Nature 455, 216-219.

Schmidt, B.C., Behrens, H., 2008. Water solubility in phonolite melts: influence of melt composition and temperature. Chem. Geol. 256, 259-268.

Taylor, J.R., Wall, V.J. \& Pownceby, M.I. (1992). The calibration and application of accurate redox sensors. American Mineralogist 77, 284-295.

Triebold, S., Kronz, A., Wörner, G., 2006. Anorthite-calibrated backscattered electron profiles, trace elements, and growth textures in feldspars from the Teide-Pico viejo volcanic complex (Tenerife). J. Volcanol. Geotherm. Res. 154, 117-130. 
Van Orman, J., Crispin, K.L., 2010. Diffusion in Oxides. Rev. Mineral. Geochem. 72, $757-826$

Wiesmaier, S., Troll, V.R., Carracedo, J.C., Ellam, R.M., Bindeman, Y., Wolff, J.A.,

2012. Bimodality of Lavas in the Teide-PicoViejo Succession inTenerife-the Role of Crustal Melting in the Origin of Recent Phonolites . J. Petrol. doi:10.1093/petrology/egs056 


\section{Figure captions}

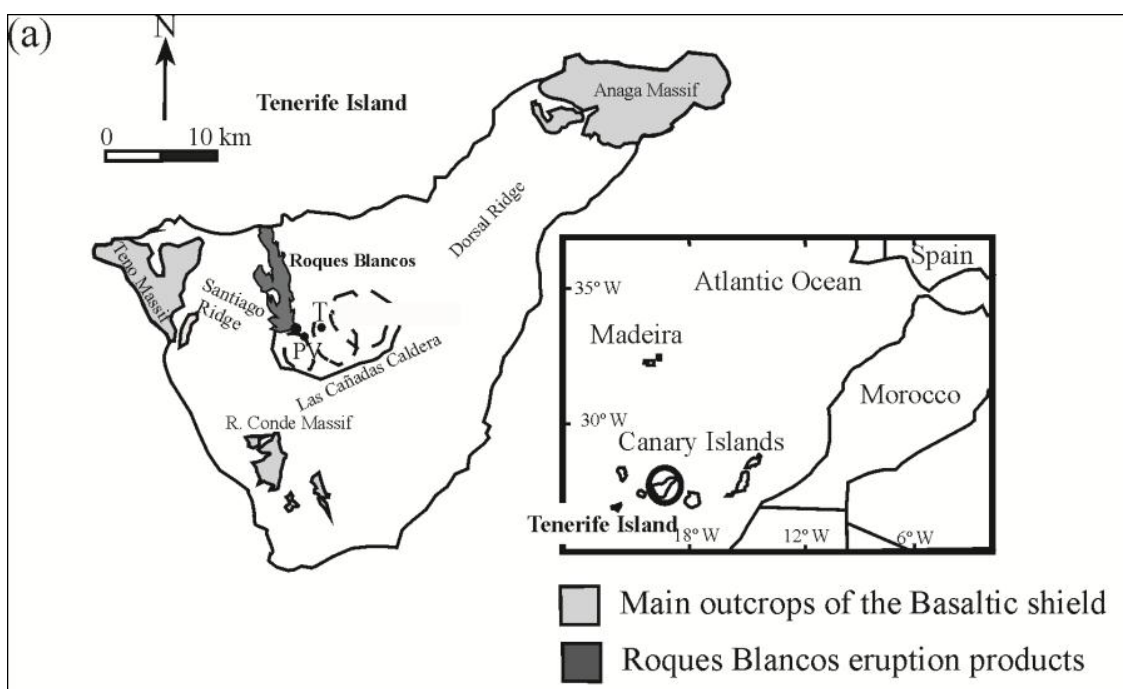

(b)

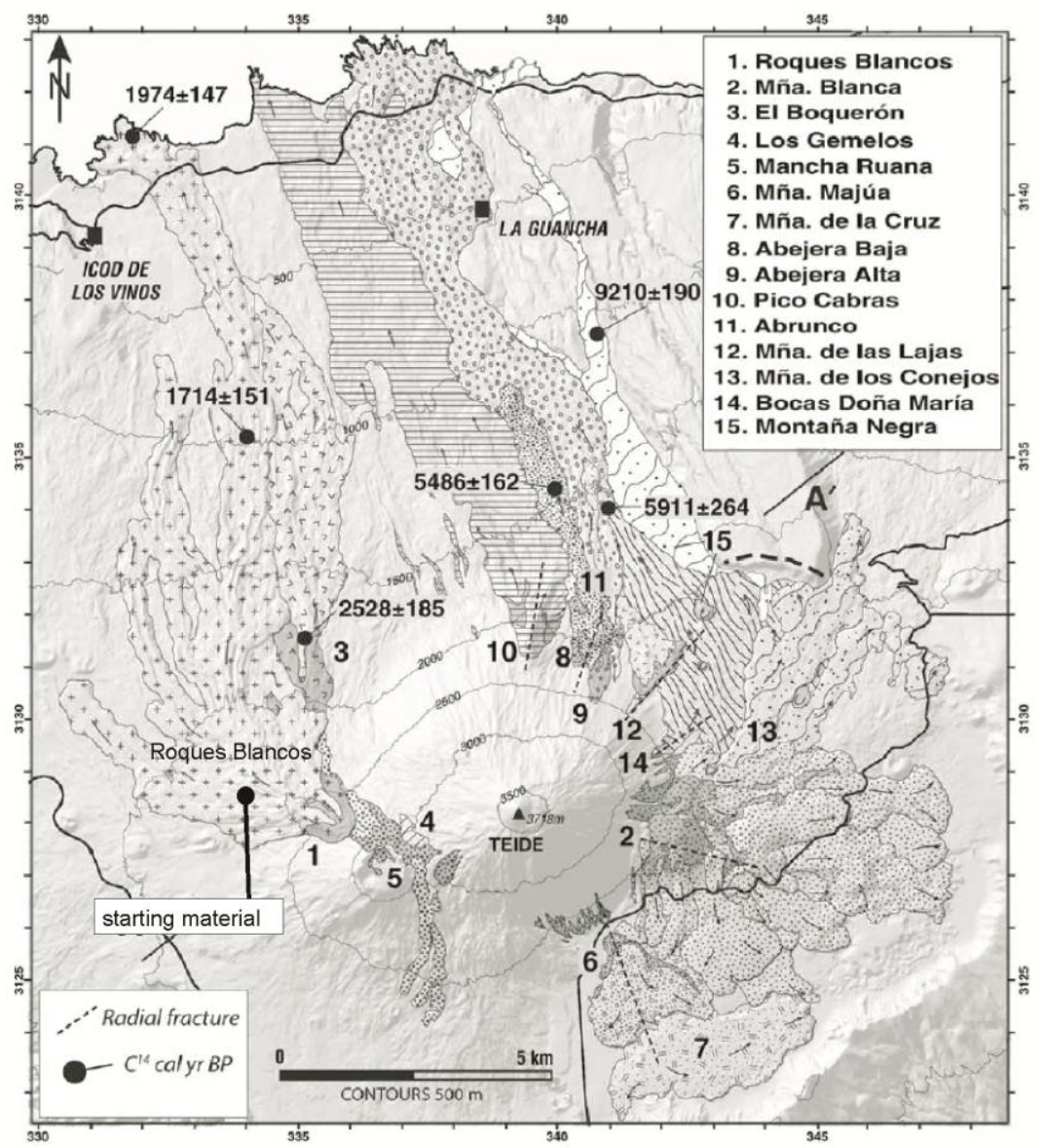




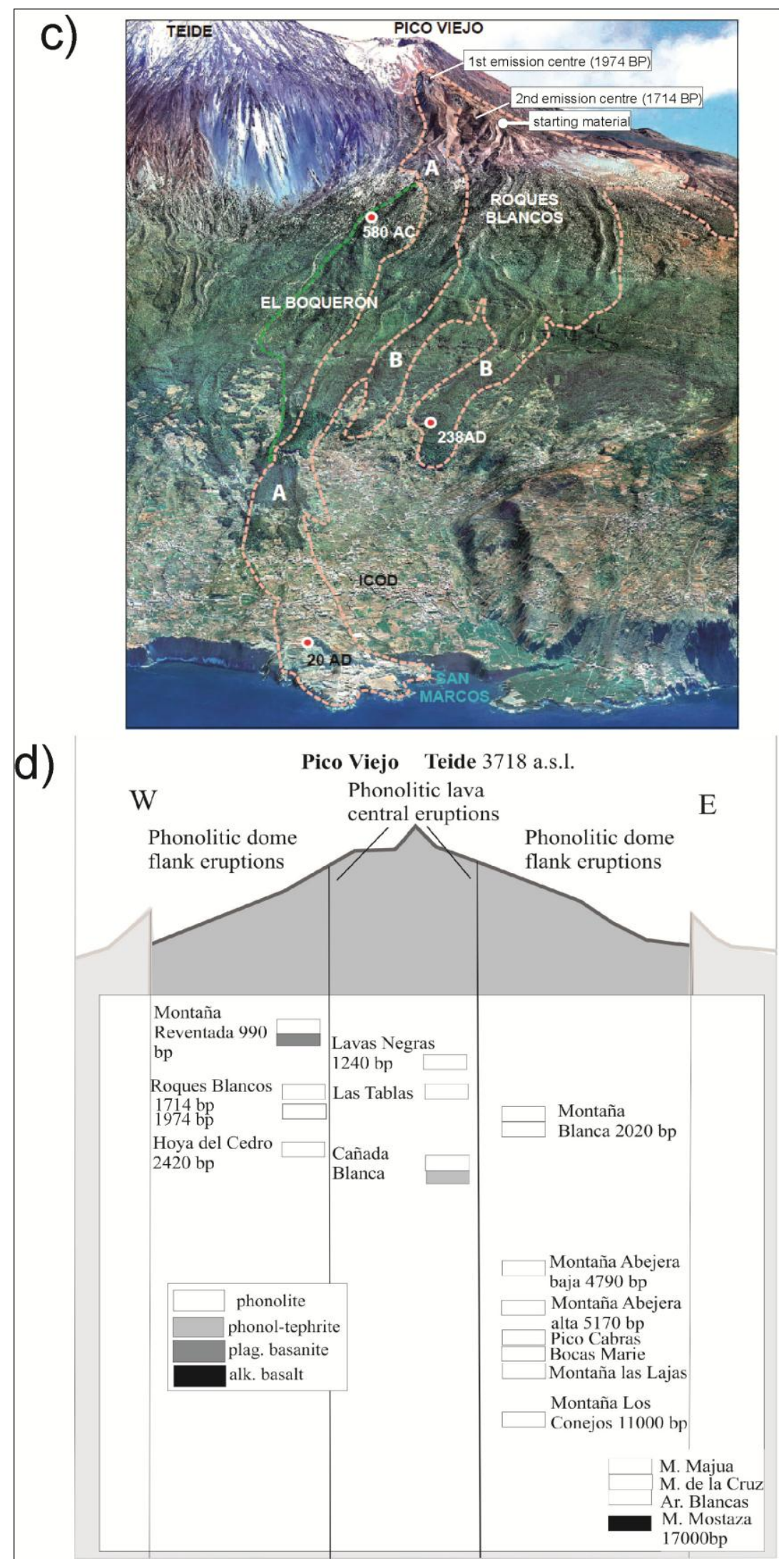

Figure 1. a) Geographic location of the Canary Islands and simplified geological map of Tenerife showing the products of the ancient basaltic shield, the las Cañadas Caldera depression and the actual volcanic complex of Teide (T), Pico Viejo (PV), the vent and 
distribution of the Roques Blancos eruption products (Modified from Ablay and Martí, 2000).b) geological map of the flank dome eruptions of the Teide-Pico Viejo volcano and calibrated ages (modified from Carracedo et al., 2007);c) W view picture of the Roques Blancos flank dome and location of the corresponding vents (modified from Carracedo and Rodruíguez-Badiola, 2006); d) Summary of the last $17.000 \mathrm{yr}$ stratigraphy of the Teide-Pico Viejo volcanic complex (Modified from Ablay and Martí, 2000; Geochronology from Carracedo et al., 2007). Note the difference in the number of phonolitic events from Pico Teide central eruptions compared to those from flank vents. 


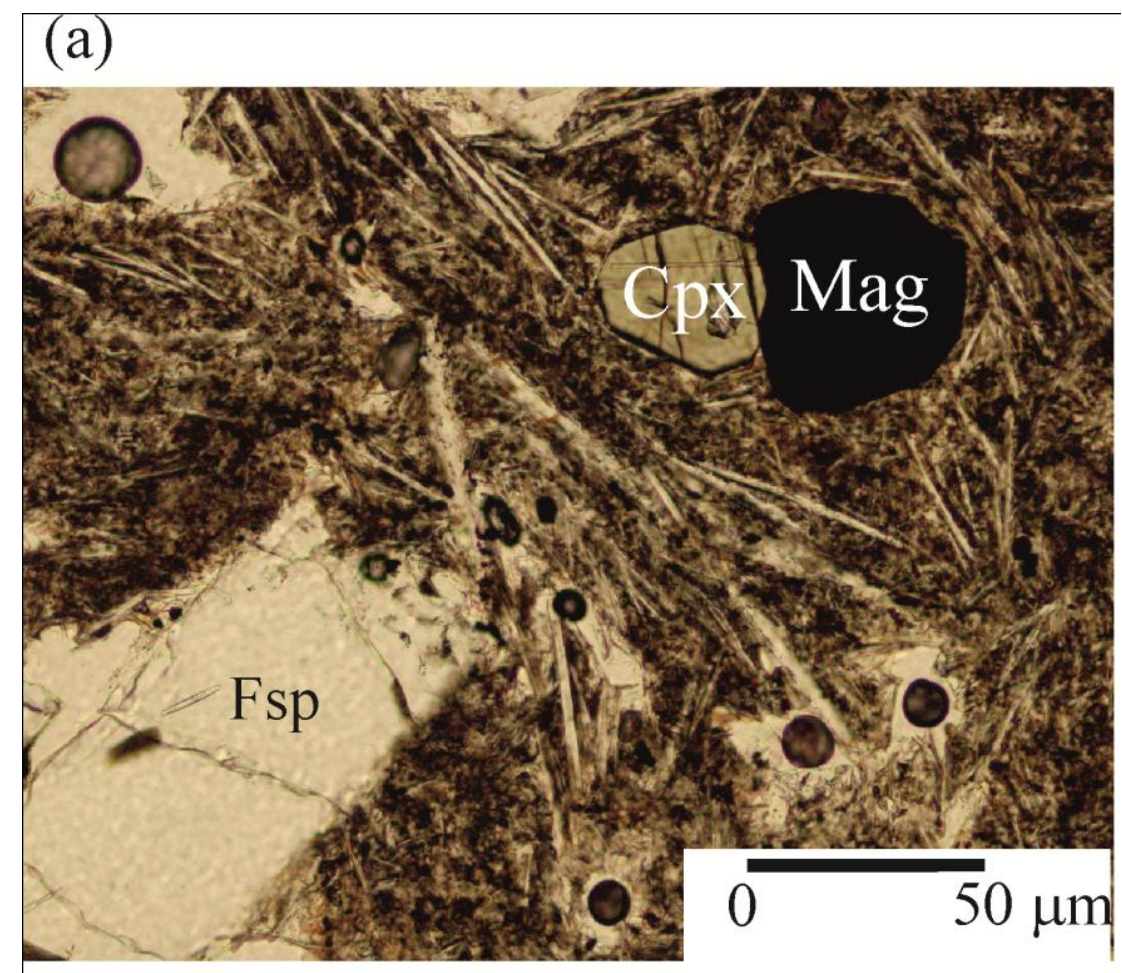

(b)

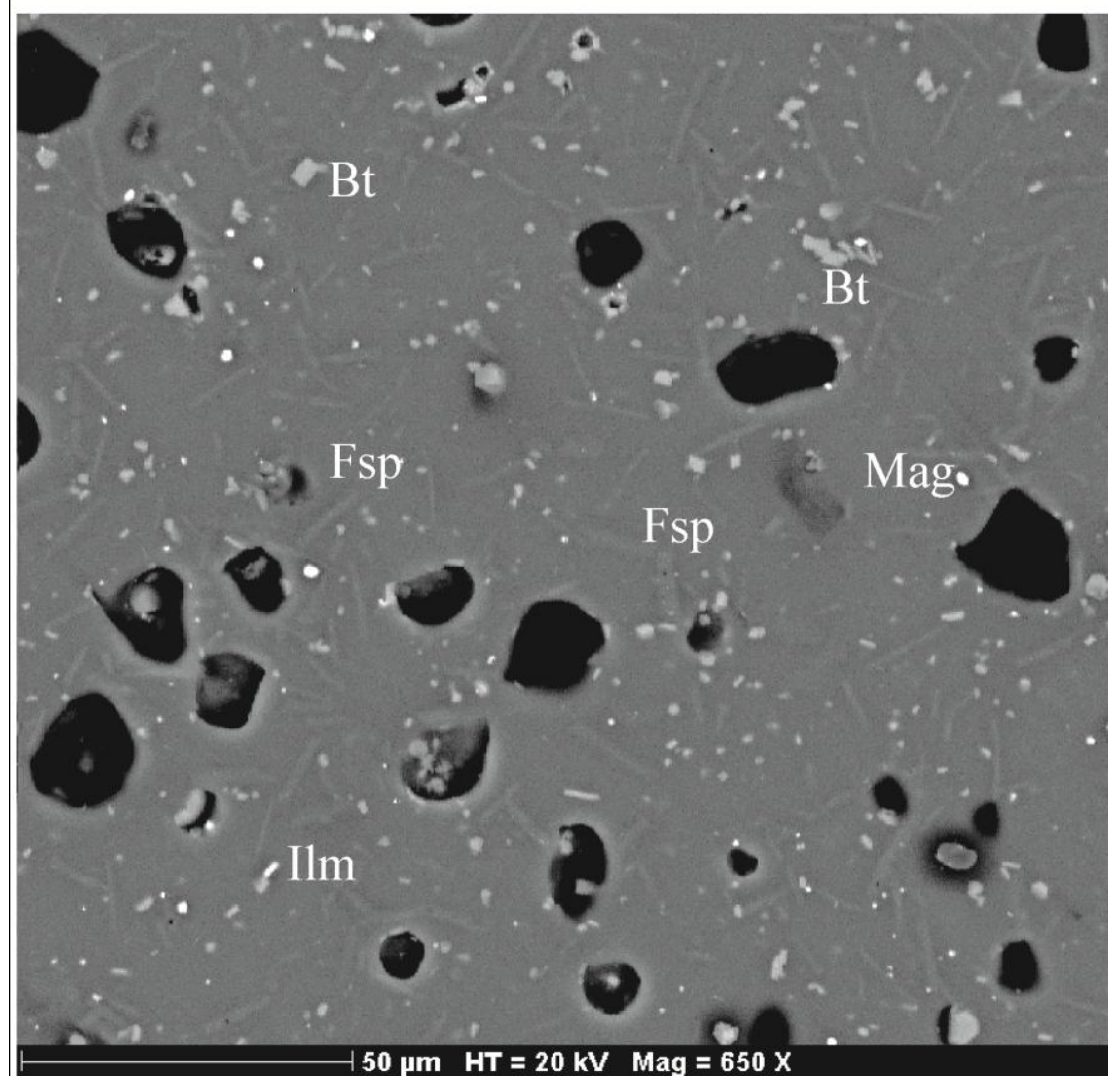

Figure 2. Photomicrograph of the Roques Blancos phonolite (Fsp: feldspar, Cpx: clinopyroxene, Mag: magnetite); b) Backscattered SEM image of an experimental 
charge containing magnetite (mag), ilmenite (ilm), biotite (bt) and feldspar (fsp). Crystals are euhedral, small and unzoned. 

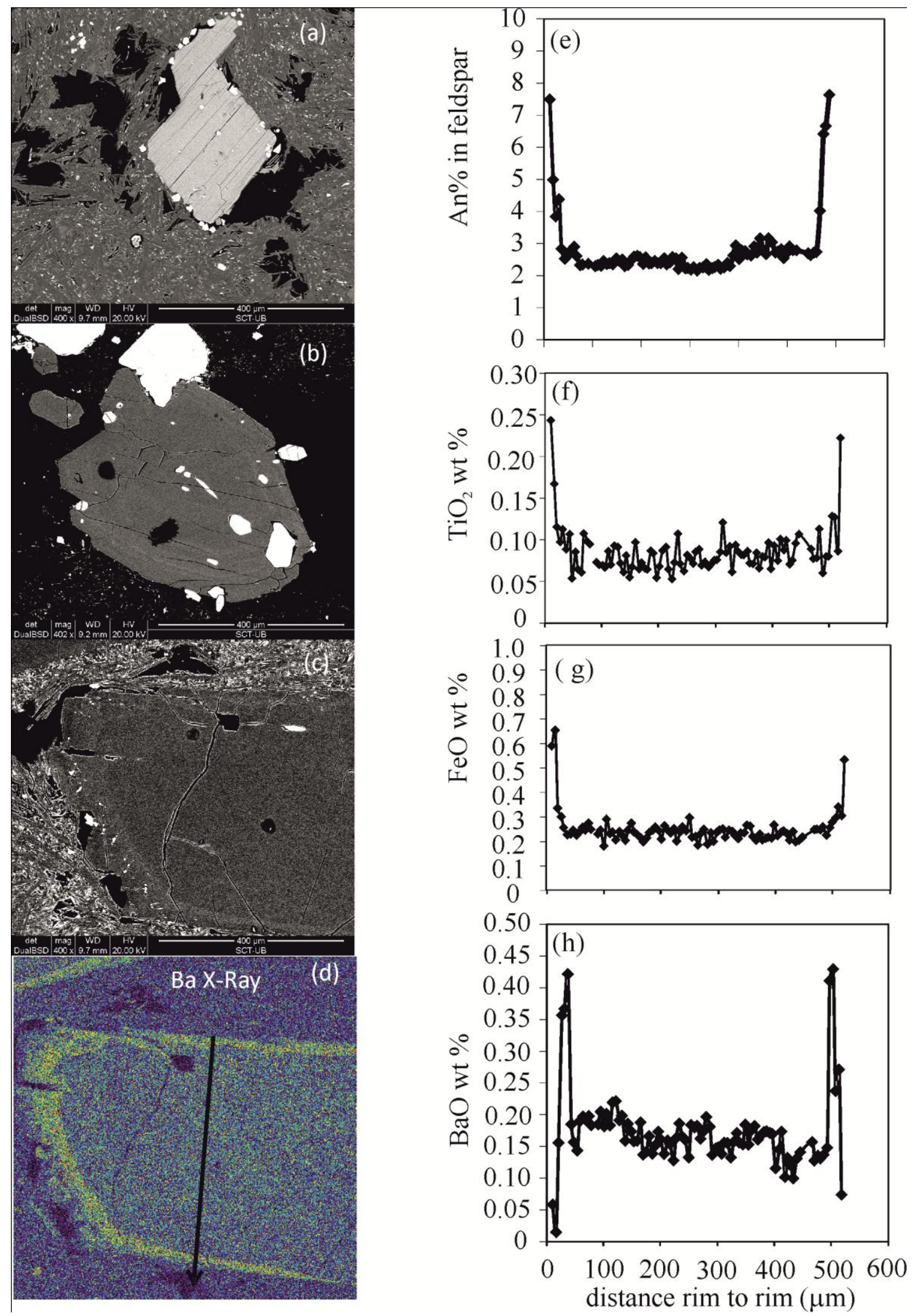

Figure 3. Example of Electron Microprobe compositional profile (rim to rim) of a natural feldspar showing a) variation in An content, b) $\left.\mathrm{TiO}_{2} \mathrm{wt}^{2}, \mathrm{c}\right) \mathrm{FeO}^{*}$ wt $\%$ and 
$\mathrm{BaO}$ wt $\%$ content. Note that the increase in An content towards the borders of the crystal is coupled with an increase in $\mathrm{FeO}, \mathrm{TiO}_{2}$ and $\mathrm{BaO}$ (see text for details). 

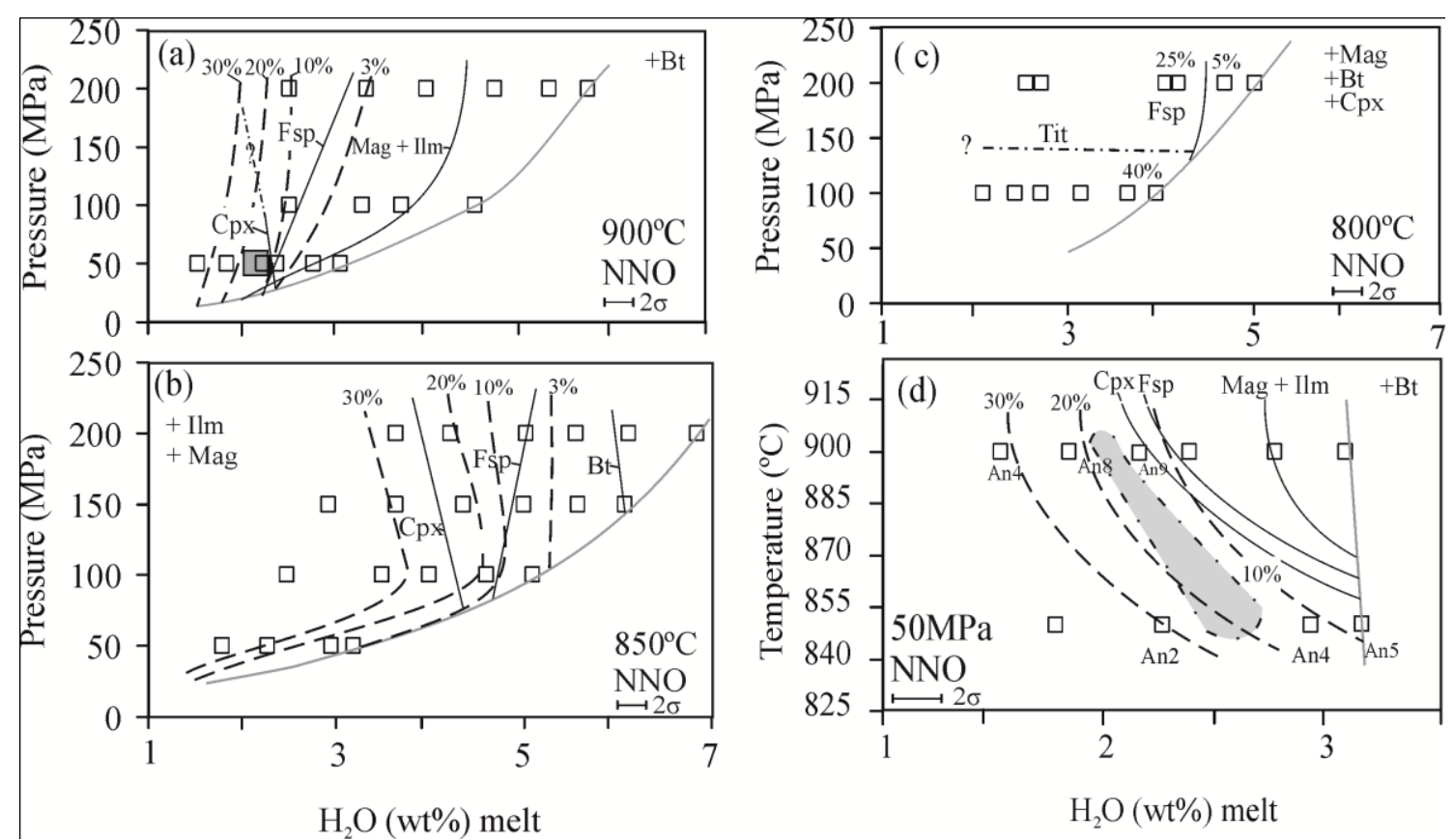

Figure 4. Isothermal phase relations of the Roques Blancos phonolite at a) $900^{\circ} \mathrm{C}$ and $f \mathrm{O}_{2} \sim \mathrm{NNO}$; b) $850^{\circ} \mathrm{C}$ and $f \mathrm{O}_{2} \sim \mathrm{NNO}$; c) $800^{\circ} \mathrm{C}$ and $f \mathrm{O}_{2} \sim \mathrm{NNO}$ for different pressures and water contents in the melt; d) Isobaric phase relations (50 $\mathrm{MPa}$ and $f \mathrm{O}_{2} \sim \mathrm{NNO}$ ) for various temperatures and water contents in the melt. Mag: magnetite, Bt: biotite, Cpx: clinopyroxene, ilm: ilmenite, tit: titanite, fsp: alkali feldspar. Dashed lines are estimated phase boundaries. Numbers above dashed lines indicate crystal content in wt (\%). Label $A n$ below squares in plate $\mathrm{d}$ indicates the An content of experimental feldspars in the charge. Dashed and dotted lines in plates a and $\mathrm{c}$ indicate estimated phase boundaries for cpx and tit. Grey band in plate a and d shows the region where the phenocrysts content and mineral assemblage of the natural obsidian are reproduced (see text for details). 


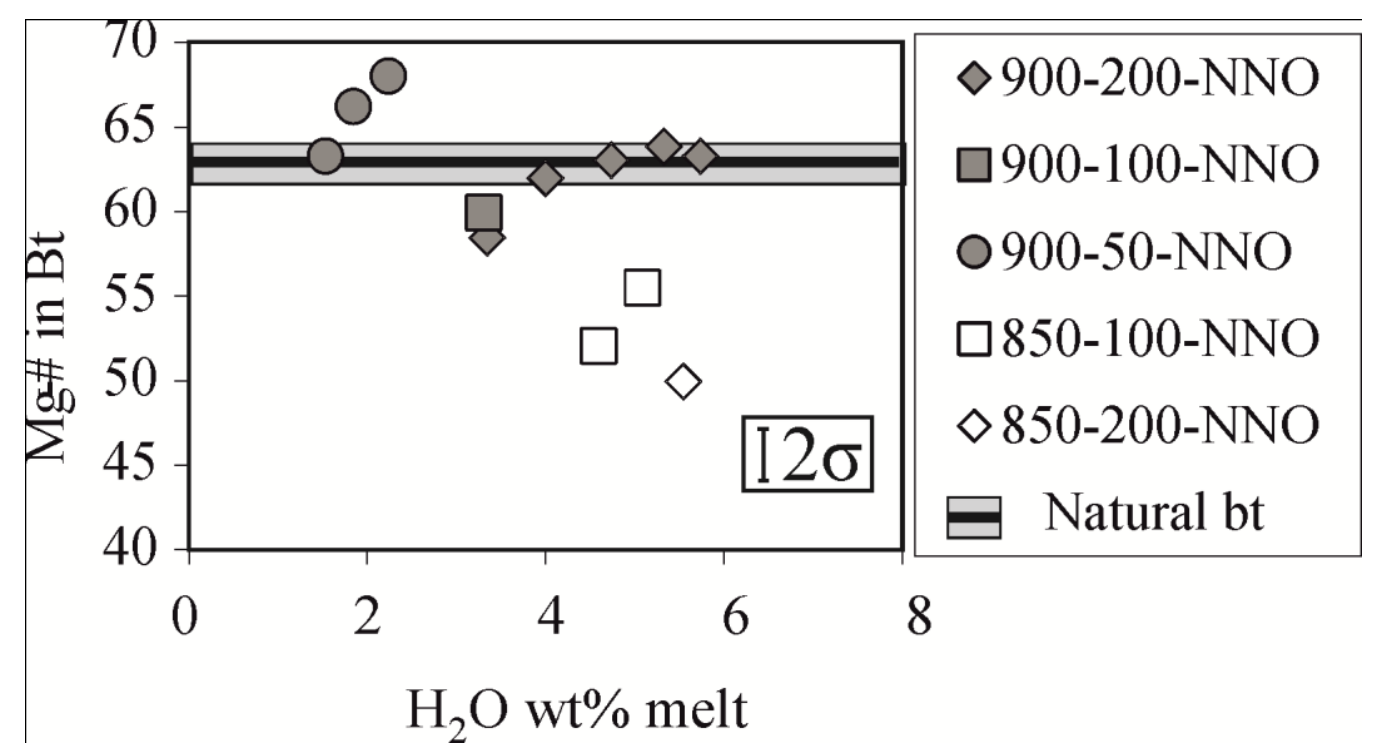

Figure 5. a) Variation of the $\mathrm{Mg \#}$ with water content in the melt of natural and experimental biotites. Black line and grey horizontal bar shows the natural composition. Numbers next to symbols in the legend indicate temperature, pressure and $f \mathrm{O}_{2}$ conditions. 


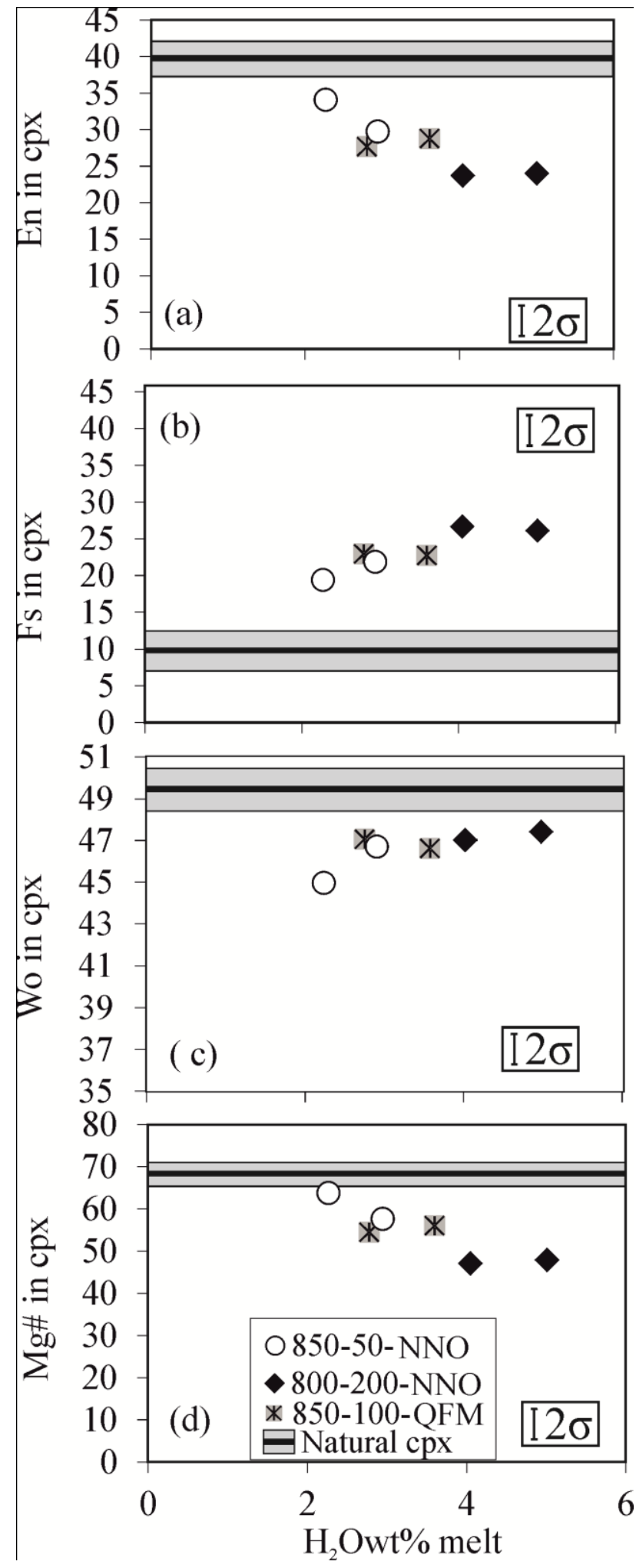

Figure 6. Variation of a) En content, b) Fs content, c) Wo content and d) $\mathrm{Mg \#}$ of experimental and natural clinopyroxenes with water content in the melt. Black line and grey horizontal bar shows the natural composition. Numbers next to symbols in the legend indicate temperature, pressure and $\mathrm{fO}_{2}$ conditions. 


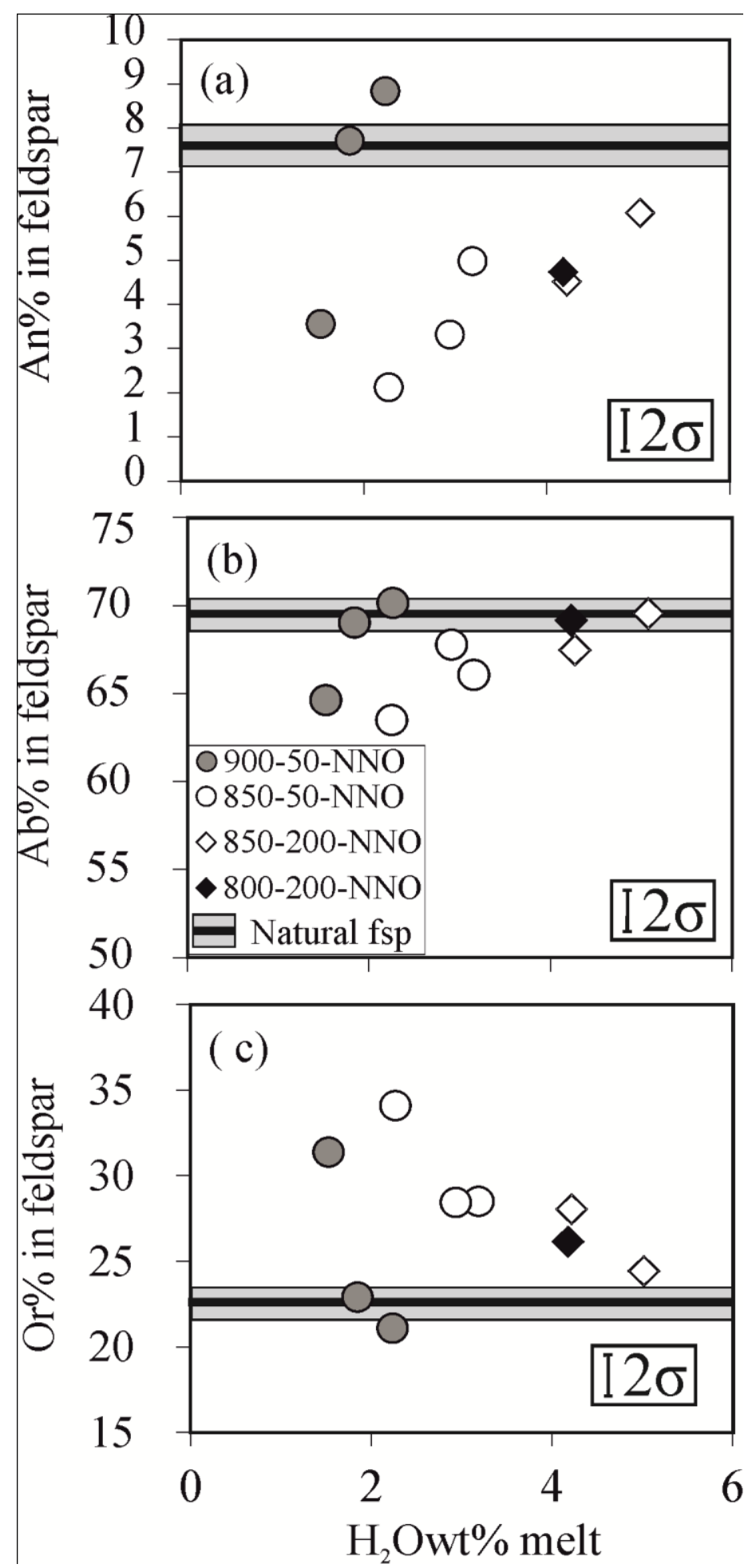

Figure 7. Variation of a) Anorthite content, b) albite content and c) orthose content in natural and experimental feldspars with water content in the melt. Black line and grey horizontal bar shows the natural composition. Numbers next to symbols in the legend indicate temperature, pressure and $f \mathrm{O}_{2}$ conditions. 


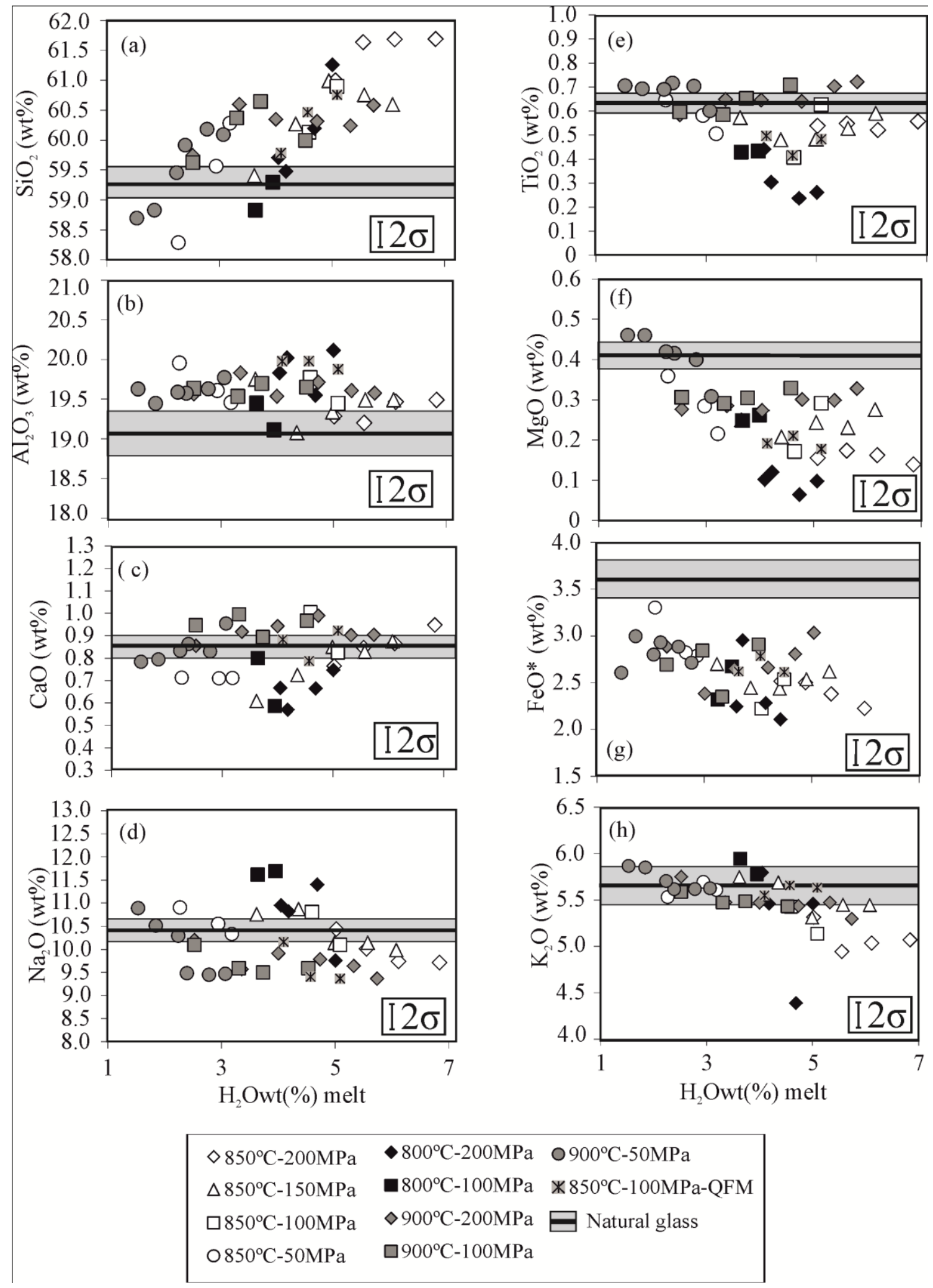

Figure 8. Glass compositional variations of major and minor oxides with water content in the melt (plates a to h). Black line and grey horizontal bar shows the natural composition. Numbers next to symbols in the legend indicate temperature, pressure and $\mathrm{fO}_{2}$ conditions. 


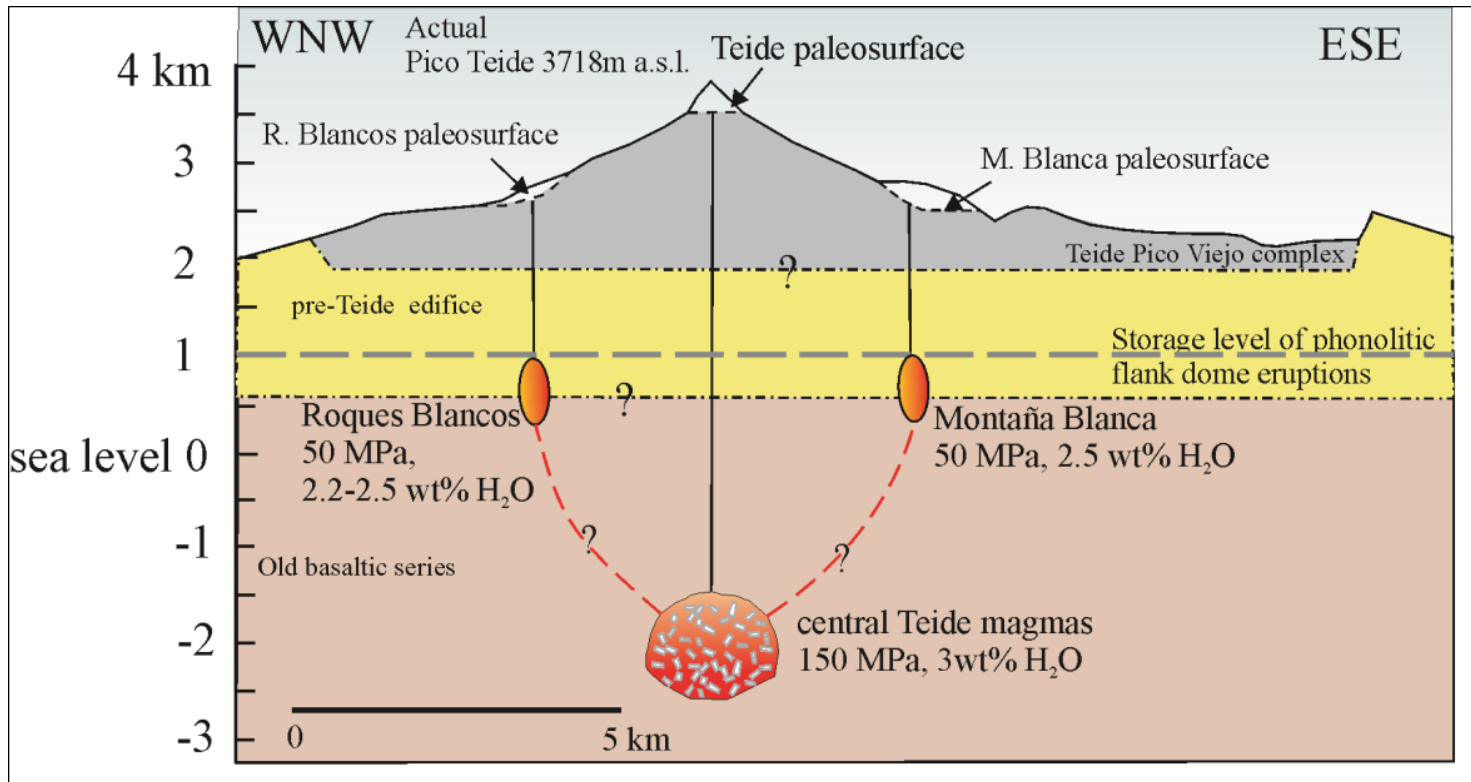

Figure 9. WNW-ESE cross section of the Teide-Pico Viejo stratovolcano showing the the location of the magmatic reservoirs for central Teide magmas (Andújar et al. 2010), Montaña Blanca (Andújar and Scaillet, 2012a) and Roques Blancos (this work). Magma reservoir volumes are not at scale (modified from Andújar and Scaillet, 2012a). 
Table 1: Major element compositions (in wt\%) of bulk-rock, glass, and minerals of the natural sample, and starting material.

\begin{tabular}{|c|c|c|c|c|c|c|c|c|c|c|c|c|c|c|}
\hline & bulk rock a & $\begin{array}{c}\text { starting } \\
\text { material b }\end{array}$ & $\begin{array}{c}\text { calculated } \\
\text { glass c }\end{array}$ & sd & magnetite & sd & anorthoclase & sd & diopside & sd & biotite & sd & ilmenite & sd \\
\hline $\mathrm{n}$ & & 15 & & & 6 & & 17 & & 8 & & 10 & & 6 & \\
\hline $\mathrm{SiO}_{2}$ & 59,38 & 59,64 & 59,23 & 0,33 & 0,08 & 0,01 & 65,11 & 0,40 & 51,36 & 0,41 & 36,66 & 0,28 & 0,05 & 0,01 \\
\hline $\mathrm{TiO}_{2}$ & 0,66 & 0,74 & 0,63 & 0,06 & 16,71 & 0,58 & 0,09 & 0,02 & 0,85 & 0,13 & 7,31 & 0,15 & 48,45 & 0,22 \\
\hline $\mathrm{Al}_{2} \mathrm{O}_{3}$ & 18,89 & 19,41 & 19,01 & 0,23 & 1,00 & 0,01 & 19,72 & 0,29 & 1,37 & 0,18 & 12,55 & 0,15 & 0,10 & 0,00 \\
\hline $\mathrm{MgO}$ & 0,41 & 0,48 & 0,41 & 0,05 & 2,09 & 0,09 & 0,00 & 0,00 & 12,59 & 0,39 & 13,87 & 0,17 & 2,96 & 0,12 \\
\hline $\mathrm{CaO}$ & 0,88 & 0,80 & 0,86 & 0,09 & 0,16 & 0,20 & 0,93 & 0,20 & 21,66 & 0,24 & 0,00 & 0,00 & 0,10 & 0,04 \\
\hline $\mathrm{MnO}$ & 0,19 & 0,14 & 0,21 & 0,02 & 2,50 & 0,01 & 0,00 & - & 0,83 & 0,03 & 0,00 & 0,00 & 3,26 & 0,03 \\
\hline $\mathrm{FeO} *$ & 3,41 & 3,39 & 3,62 & 0,18 & 72,13 & 0,23 & 0,25 & 0,03 & 10,07 & 0,52 & 14,60 & 0,19 & 42,95 & 0,55 \\
\hline $\mathrm{Na}_{2} \mathrm{O}$ & 9,90 & 9,90 & 10,37 & 0,19 & - & - & 7,94 & 0,19 & 1,16 & 0,08 & 1,07 & 0,12 & - & - \\
\hline $\mathrm{K}_{2} \mathrm{O}$ & 5,48 & 5,49 & 5,65 & 0,12 & - & - & 4,81 & 0,42 & 0,00 & 0,00 & 8,45 & 0,08 & - & - \\
\hline $\mathrm{P}_{2} \mathrm{O}_{5}$ & 0,07 & - & & - & - & - & - & - & - & - & - & - & - & - \\
\hline $\mathrm{Cl}$ & 0,30 & - & & - & - & - & - & - & - & - & - & - & - & - \\
\hline $\mathrm{F}$ & 0,12 & - & & - & - & - & - & - & - & - & - & - & - & - \\
\hline Original Sum & 99,69 & 100,0 & 100,0 & & 94,7 & 0,2 & 98,9 & 0,3 & 99,9 & 0,6 & 94,5 & & 97,9 & 0,0 \\
\hline Mg\# & & & 16,96 & & 4,90 & & & & 69,03 & 1,01 & 62,87 & 0,39 & & \\
\hline An & & & & & & & 4,44 & 0,95 & & & & & & \\
\hline $\mathrm{Ab}$ & & & & & & & 68,30 & 1,47 & & & & & & \\
\hline Or & & & & & & & 27,26 & 2,35 & & & & & & \\
\hline Wo & & & & & & & & & 49,6 & 0,3 & & & & \\
\hline En & & & & & & & & & 40,1 & 1,1 & & & & \\
\hline Fs & & & & & & & & & 10,3 & 1,2 & & & & \\
\hline $\begin{array}{l}\text { Phase } \\
\text { proportions } \\
\text { (wt } \% \text { ) }\end{array}$ & & & 85,60 & & 0,30 & & 13,70 & & 0,08 & & 0,30 & & 0,10 & \\
\hline
\end{tabular}

Thermo-Oxybarometric results after Sauerzapf et al. (2008)

$\begin{array}{lcc}\text { n. pairs } & 6 & \text { sd } \\ \mathrm{T}\left({ }^{\circ} \mathrm{C}\right) & 895,37 & 4,8 \\ \Delta \mathrm{NNO}^{\mathrm{d}} & -0,19 & 0,10 \\ \log f \mathrm{O}_{2} & -12,19 & 0,02\end{array}$

a: Bulk rock composition of the natural sample analysed by ICP-MS.

b: Electron Microprobe analysis of the starting glass added to the capsules.

c: Composition of the residual melt calculated by mass balance using the composition and abundance of the mineral phases and the bulk rock.

sd: Standard deviation.

n: Number of analysis.

*: Total iron reported as $\mathrm{Fe}^{2+}$.

$\mathrm{Mg} \#=100\left[\mathrm{Mg} /\left(\mathrm{Mg}+\mathrm{Fe}^{*}\right)\right]$

Or, Ab, and An end- members calculated as in Deer et al. (1972)

End members for clinopyroxene (En, Fs, Wo) calculated as in Morimoto (1989).

phase proportions calculated as weight $\%$.

d:Values for NNO buffer after Pownceby \& O'Neill (1994) 
NNO experiments

\begin{tabular}{|c|c|c|}
\hline Run & $\mathrm{XH}_{2} \mathrm{Owt} \%_{\text {in }}$ & $\mathrm{H} 2 \mathrm{Owt} \%_{\text {melt }}$ \\
\hline $850^{\circ} \mathrm{C}$ & $162 \mathrm{~h}$ & $\mathrm{~b}$ \\
\hline RB1 & 1,00 & 6,84 \\
\hline RB2 & 0,89 & 6,12 \\
\hline RB3 & 0,81 & 5,55 \\
\hline RB4 & 0,73 & 5,02 \\
\hline RB5 & 0,62 & 4,22 \\
\hline RB & & \\
\hline
\end{tabular}

$850^{\circ} \mathrm{C}, 150 \mathrm{MPa}, 233 \mathrm{~h}$

$\begin{array}{ll}\text { RB25 } & 1,00 \\ \text { RB26 } & 0,92\end{array}$

RB27 $\quad 0,82$

RB28 $\quad 0,72$

RB29 $\quad 0,60$

RB30 $\quad 0,48$

$850^{\circ} \mathrm{C}, 100 \mathrm{MPa}, 195 \mathrm{~h}$

$\mathrm{RB} 13 \quad 1,00$

RB14 $\quad 0,90$

RB15 $\quad 0,78$

RB16 $\quad 0,69$

$\mathrm{RB} 18 \quad 0$

$850^{\circ} \mathrm{C}, 50 \mathrm{MPa}, 389 \mathrm{~h}$

RB31 1,00

RB32 $\quad 0,92$

RB34 $\quad 0,7$

RB35 $\quad 0,5$

$800^{\circ} \mathrm{C}, 205 \mathrm{MPa}, 114 \mathrm{~h}$

RB49 1,00

RB50 0,94

RB51 0,84

RB52 0,81

RB53 $\quad 0,54$

RB54

0,51

$800^{\circ} \mathrm{C}, 100 \mathrm{MPa}, 145 \mathrm{~h}$

RB61 1,00

RB62

RB63

RB64

RB65

RB66

0,80
0,69

0,62

0,53 $f \mathrm{H}_{2}$ (bar)

$\log f \mathrm{O}_{2}$ (bar)

$-12,69$

$-12,71 \quad 0,14$

$\begin{array}{ll}-12,90 & -0,05\end{array}$

$-13,07$

$-13,24$

$-13,55$

$-13,80$

$6,47^{\mathrm{d}}$

$-12,76$

$-12,76$

$-12,88$

$-13,07$

$-13,3$

$-13,63$
$-13,99$

$5,6^{\mathrm{d}}$

$-12,88$

$-12,87$

$-12,97$

$-13,22$

$-13,45$

$2,42^{\mathrm{c}}$$$
-14,03
$$$$
-12,71
$$$$
-12,84
$$

$-12,98$

$-13,42$

$-13,81$

$-13,71$

$-13,70$
$-13,81$

$-13,81$
$-13,97$

$-14,10$

4,18

4,05

2,56

$4,92^{\mathrm{d}}$

$$
-13,87
$$

$-13,87$
$-13,93$

0,03

0,03
$-0,05$

0,13

0,10

$-0,45$

$-0,77$

$-1,12$

0,01

0,00
$-0,10$

$-0,58$

$-1,16$

0,18
0,04

$-0,10$

$-0,54$

$-0,93$

0,19

$-0,11$
$\mathrm{aH}_{2} \mathrm{O}^{\mathrm{e}}$ phase assemblage

$0,98 \quad(98.2) \mathrm{gl}+(1.6) \mathrm{mag}+(0.2) \mathrm{ilm}$

0,78 (98.2) $\mathrm{gl}+(1.4) \mathrm{mag}+(0.4) \mathrm{ilm}$

$0,65 \quad(93.0) \mathrm{gl}+(1.0) \mathrm{mag}+($ trace $) \mathrm{ilm}+(6.0) \mathrm{b}$

$0,53 \quad(94.7) \mathrm{gl}+(0.3) \mathrm{mag}+(0.3) \mathrm{ilm}+(4.7) \mathrm{bt}+($ trace $) \mathrm{fsp}$

$0,37 \quad \mathrm{gl}+\mathrm{mag}+\mathrm{ilm}+\mathrm{bt}+\mathrm{fsp}$

$0,28 \quad$ gl+mag+ilm+bt+fsp+cpx

$-0,02$
$-0,21$

$1,00 \quad(97.3) \mathrm{gl}+(0.7) \mathrm{mag}+($ trace $) i \mathrm{~lm}+(2.0) \mathrm{bt}$

(96.7)gl+(0.6) mag+(trace)ilm+(2.74)bt

(96.5) $\mathrm{gl}+(0.1) \mathrm{mag}+(\mathrm{tace}) \mathrm{ilm}+(3.4) \mathrm{bt}$

(78.7) $\mathrm{gl}+(0.7) \mathrm{mag}+($ trace $) \mathrm{ilm}+(3.6) \mathrm{bt}+(17.0) \mathrm{fsp}$

(75.5)gl+(1.2)mag+(trace)ilm+(1.6)bt+(20.9)fsp+(0.8)cpx

gl+mag+ilm+bt+fsp+cpx

$-0,10$
$-0,35$

$1,00 \quad(95.9) \mathrm{gl}+(0.7) \mathrm{mag}+($ trace $) \mathrm{ilm}+(3.4) \mathrm{bt}$

$0,89 \quad(78.9) \mathrm{gl}+(1.3) \mathrm{mag}+($ trace $) \mathrm{lm}+(2.6) \mathrm{bt}+(17.2) \mathrm{fsp}$

$0,67 \quad(72.7) \mathrm{gl}+(1.5) \mathrm{mag}+($ trace $) \mathrm{ilm}+(3.1) \mathrm{bt}+(22.7) \mathrm{fsp}+($ trace $) \mathrm{cpx}$

$0,51 \quad$ gl+mag+ilm+bt+fsp+cpx

$0,26 \quad \mathrm{gl}+\mathrm{mag}+\mathrm{ilm}+\mathrm{bt}+\mathrm{fsp}+\mathrm{cpx}$

$0,86 \quad(92.3) \mathrm{gl}+(0.5) \mathrm{mag}+(0.1) \mathrm{ilm}+(2.2) \mathrm{bt}+(4.8) \mathrm{fsp}+(0.1) \mathrm{cpx}$

$0,73 \quad(82.8) \mathrm{gl}+(1.0) \mathrm{mag}+($ trace $) \mathrm{ilm}+(1.5) \mathrm{bt}+(14.4) \mathrm{fsp}+(0.3) \mathrm{cpx}$

$0,44 \quad(70.8) \mathrm{gl}+(0.9) \mathrm{mag}+($ trace $) \mathrm{ilm}+(1.4) \mathrm{bt}+(26.4) \mathrm{fsp}+(0.5) \mathrm{cpx}$

$0,28 \quad \mathrm{gl}+\mathrm{mag}+\mathrm{ilm}+\mathrm{bt}+\mathrm{fsp}+\mathrm{cpx}$

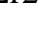

1,03

0,90

1,20

n.

0,16

0,93

(95.9) $\mathrm{gl}+(1.3) \mathrm{mag}+(2.5) \mathrm{bt}+(0.3) \mathrm{cpx}$

(95.4) $\mathrm{gl}+(0.5) \mathrm{mag}+(3.3) \mathrm{bt}+(0.8) \mathrm{cpx}$

$(76.9) \mathrm{gl}+(0.6) \mathrm{mag}+(2.4) \mathrm{bt}+(1.0) \mathrm{cpx}+(19.2) \mathrm{fsp}$

(73.5)gl+(1.5) mag+(1.6)bt+(0.5) cpx+(22.9) fsp

$\mathrm{gl}+\mathrm{mag}+\mathrm{bt}+\mathrm{cpx}+\mathrm{fsp}$

$\mathrm{gl}+\mathrm{mag}+\mathrm{bt}+\mathrm{cpx}+\mathrm{fsp}$

0,06

0,06

0,33

0,05

n.d.

0,21

0,12

, 12

n.d.

0,06

0,01

0,10

n.d.

0,38

0,50

0,19

0,07

n.d.

(61.6)gl+(1.4)mag+(2.8)bt+(0.5)cpx+(33.7)fsp+(trace)tit

(60.7)gl+(1.9) mag+(1.7)bt+(trace)cpx+(35.7)fsp+(trace)tit

gl+mag+bt+cpx+fsp+tit

gl+mag+bt+cpx + fsp + tit

$\mathrm{gl}+\mathrm{mag}+\mathrm{bt}+\mathrm{cpx}+\mathrm{fsp}+\mathrm{tit}$

$\mathrm{gl}+\mathrm{mag}+\mathrm{bt}+\mathrm{cpx}+\mathrm{fsp}+\mathrm{tit}$

0,14

0,08

n.d

n.d.

n.d. 


\begin{tabular}{|c|c|c|c|c|c|c|c|c|}
\hline \multicolumn{2}{|c|}{$900^{\circ} \mathrm{C}, 200 \mathrm{MPa}, 164 \mathrm{~h}$} & a & \multirow[t]{7}{*}{$8,36^{\mathrm{c}}$} & $-11,69$ & \multicolumn{2}{|l|}{0,27} & \multirow[b]{2}{*}{$(97.5) \mathrm{gl}+(2.5) \mathrm{bt}$} & \multirow[b]{2}{*}{0,73} \\
\hline RB85 & 1,00 & 5,74 & & $-12,11$ & $-0,19$ & 0,69 & & \\
\hline RB86 & 0,93 & 5,33 & & $-12,23$ & $-0,31$ & 0,60 & $(97.5) \mathrm{gl}+(2.5) \mathrm{bt}$ & 0,43 \\
\hline RB87 & 0,83 & 4,74 & & $-12,44$ & $-0,52$ & 0,47 & $(97.3) \mathrm{gl}+(2.7) \mathrm{bt}$ & 0,39 \\
\hline RB88 & 0,70 & 4,00 & & $-12,74$ & $-0,81$ & 0,34 & $(97.8) \mathrm{gl}+(0.9) \mathrm{mag}+(\operatorname{trace}) \mathrm{ilm}+(1.3) \mathrm{bt}$ & 0,06 \\
\hline RB89 & 0,58 & 3,35 & & $-13,04$ & $-1,12$ & 0,24 & (97.7)gl+(1.4)mag+(trace)ilm+(0.4)bt & 0,35 \\
\hline RB90 & 0,44 & 2,53 & & $-13,52$ & $-1,60$ & 0,14 & (88.1)gl+(0.9)mag + (trace) $\mathrm{ilm}+(0.7) \mathrm{bt}+(10.3) \mathrm{fsp}$ & 0,07 \\
\hline \multicolumn{2}{|c|}{$900^{\circ} \mathrm{C}, 100 \mathrm{MPa}, 188 \mathrm{~h}$} & $\mathrm{a}$ & $4,89^{\mathrm{d}}$ & $-11,81$ & 0,15 & & & \\
\hline RB 91 & 1,00 & 4,53 & & $-11,94$ & 0,00 & 0,86 & $(98.4) \mathrm{gl}+(1.6) \mathrm{bt}$ & 0,34 \\
\hline RB 93 & 0,82 & 3,73 & & $-12,27$ & $-0,33$ & 0,59 & $(98.2) \mathrm{gl}+(1.5) \mathrm{mag}+(\operatorname{trace}) \mathrm{ilm}+(0.3) \mathrm{bt}$ & 0,37 \\
\hline RB 94 & 0,73 & 3,31 & & $-12,48$ & $-0,54$ & 0,46 & $(98.2) \mathrm{gl}+(0.6) \mathrm{mag}+(0.2) \mathrm{ilm}+(0.7) \mathrm{bt}$ & 0,30 \\
\hline RB 95 & 0,56 & 2,53 & & $-12,94$ & $-1,00$ & 0,27 & $(89.8) \mathrm{gl}+(1.0) \mathrm{mag}+($ trace $) \mathrm{ilm}+(0.3) \mathrm{bt}+(8.9) \mathrm{fsp}$ & 0,11 \\
\hline \multicolumn{2}{|c|}{$900^{\circ} \mathrm{C}, 50 \mathrm{MPa}, 284 \mathrm{~h}$} & $\mathrm{a}$ & $3,53^{\mathrm{c}}$ & $-11,75$ & 0,21 & & & \\
\hline RB 96 & 1,00 & 3,07 & & $-11,95$ & 0,01 & 0,80 & $(98.2) \mathrm{gl}+(1.8) \mathrm{bt}$ & 0,30 \\
\hline RB 97 & 0,91 & 2,78 & & $-12,11$ & $-0,16$ & 0,66 & $(98.4) \mathrm{gl}+(1.6) \mathrm{bt}$ & 0,57 \\
\hline RB 98 & 0,78 & 2,39 & & $-12,37$ & $-0,41$ & 0,49 & $(98.5) \mathrm{gl}+(0.7) \mathrm{mag}+($ trace $) \mathrm{ilm}+(0.8) \mathrm{bt}$ & 0,26 \\
\hline RB 99 & 0,73 & 2,24 & & $-12,48$ & $-0,52$ & 0,43 & $(85.0) \mathrm{gl}+(1.3) \mathrm{mag}+(0.1) \mathrm{ilm}+(0.1) \mathrm{bt}+(\operatorname{trace}) \mathrm{cpx}+(13.5) \mathrm{fsp}$ & 0,08 \\
\hline RB 100 & 0,60 & 1,85 & & $-12,79$ & $-0,84$ & 0,30 & $(74.3) \mathrm{gl}+(1.3) \mathrm{mag}+(\operatorname{trace}) \mathrm{ilm}+(0.4) \mathrm{bt}+(0.2) \mathrm{cpx}+(23.8) \mathrm{fsp}$ & 0,10 \\
\hline RB 101 & 0,50 & 1,53 & & $-13,09$ & $-1,13$ & 0,21 & $(67.8) \mathrm{gl}+(1.8) \mathrm{mag}+(\operatorname{trace}) \mathrm{ilm}+(0.6) \mathrm{bt}+(0.2) \mathrm{cpx}+(29.6) \mathrm{fsp}$ & 0,09 \\
\hline \multicolumn{9}{|c|}{ QFM experiments } \\
\hline \multicolumn{2}{|c|}{$850^{\circ} \mathrm{C}, 100 \mathrm{MPa}, 188 \mathrm{~h}$} & $\mathrm{~b}$ & $6,66^{\mathrm{c}}$ & $-13,03$ & $-0,14$ & & & \\
\hline RB 73 & 1,00 & 5,09 & & $-13,25$ & $-0,38$ & 1,00 & $(98.0) \mathrm{gl}+(0.7) \mathrm{mag}+(0.5) \mathrm{ilm}+(0.8) \mathrm{bt}$ & 0,70 \\
\hline RB 74 & 0,90 & 4,57 & & $-13,32$ & $-0,45$ & 0,89 & $(98.3) \mathrm{gl}+(0.4) \mathrm{mag}+(0.7) \mathrm{ilm}+(\operatorname{trace}) \mathrm{bt}+(0.6) \mathrm{cpx}$ & 0,58 \\
\hline RB 75 & 0,80 & 4,09 & & $-13,48$ & $-0,61$ & 0,67 & $(88.7) \mathrm{gl}+(0.9) \mathrm{mag}+($ trace $) \mathrm{ilm}+(0.9) \mathrm{bt}+(0.5) \mathrm{cpx}+(9.0) \mathrm{fsp}$ & 0,25 \\
\hline RB 76 & 0,71 & 3,61 & & $-13,73$ & $-0,86$ & 0,51 & $g l+m a g+i l m+b t+c p x+f s p$ & n.d. \\
\hline RB 77 & 0,55 & 2,80 & & $-13,88$ & $-1,01$ & 0,31 & $g l+m a g+i l m+b t+c p x+f s p$ & n.d. \\
\hline RB 78 & 0,53 & 2,70 & & $-14,15$ & $-1,28$ & 0,26 & $g 1+m a g+i l m+b t+c p x+f s p$ & n.d. \\
\hline
\end{tabular}

$\mathrm{XH}_{2} \mathrm{O}$ wt\%in:initial $\mathrm{H}_{2} \mathrm{O} /\left(\mathrm{H}_{2} \mathrm{O}+\mathrm{CO}_{2}\right)$ in the charge

$\mathrm{H}_{2} \mathrm{Owt} \%$ melt: water content in the melt a: determined by FTIR, b:determined by the solubility model of Papale et al. (2006)

$f \mathrm{H}_{2}$ (bar):hidrogen fugacity of the experiment. c:determined by using NiPd alloy sensors, d:calculated using the data obtained from succesfull NiPd alloys (see text for details)

$\log f \mathrm{O}_{2}$ (bar): logarithm of the oxygen fugacity calculated from the experimental $f \mathrm{H}_{2}$

$\triangle \mathrm{NNO}: \log f \mathrm{O}_{2}-\log f \mathrm{O}_{2}$ of the NNO buffer calculated at P and T (Pownceby \& O'Neill,1994)

e: $\mathrm{AH}_{2} \mathrm{Ocalculated} \mathrm{by} \mathrm{using} \mathrm{H}_{2} \mathrm{Owt} \%$ at saturation/ $\mathrm{H}_{2} \mathrm{Owt} \%$ in the melt (see text for details)

n.d.: not determined

phase assemblage: numbers in brackets indicate the phase abundance in the charge in weight \%

Gl:glass, Mag:magnetite,Bt:biotite,Cpx:clinopyroxene, Ilm:ilmenite,Fsp:alkali feldspar, Tit:titanite 
Table 3: FTIR data of experimental runs

$\begin{array}{lcccccccccccc}\text { Sample } & \mathrm{n} & \text { Thickness }(\mu \mathrm{m}) & \mathrm{sd} & 5200(\mathrm{~cm}-1) & \mathrm{sd} & 4500(\mathrm{~cm}-1) & \mathrm{sd} & \text { Density }(\mathrm{g} / \mathrm{l}) \mathrm{a} & \mathrm{sd} & \mathrm{H} \mathrm{H}_{2} \mathrm{O}(\mathrm{wt} \%) \mathrm{b} & \mathrm{sd} \\ \text { RB85 } & 3 & 197,0 & 2,1 & 0,05 & 0,00 & 0,01 & 0,00 & 2579,5 & 12,0 & 5,72 & 0,60 \\ \text { RB91 } & 3 & 135,0 & 3,5 & 0,07 & 0,00 & 0,03 & 0,00 & 2641,5 & 2,6 & 4,53 & 0,12 \\ \text { RB96 } & 3 & 91,5 & 2,6 & 0,03 & 0,00 & 0,02 & 0,00 & 2672,0 & 5,3 & 3,07 & 0,23\end{array}$

$\mathrm{n}$ : number of spectra

sd:standard deviation

5200(cm-1): Absorvance intensity from the 5200 peak

4500(cm-1):Absorvance intensity from the 4500 peak

a: density of the melt calculated as in

b: Total $\mathrm{H}_{2} \mathrm{O}(\mathrm{wt} \%)$ dissolved in the melt calculated as the sum of the water from 5200 and 4500 peaks 
Table 4: Composition (wt $\%$ ) and end-members of experimental mineral phases

\section{Magnetite}

$\begin{array}{lcccccccccccc} & \mathrm{SiO}_{2} & \mathrm{TiO}_{2} & \mathrm{Al}_{2} \mathrm{O}_{3} & \mathrm{MgO} & \mathrm{CaO} & \mathrm{MnO} & \mathrm{FeO} & \mathrm{Na}_{2} \mathrm{O} & \mathrm{K}_{2} \mathrm{O} & \mathrm{Sum} & \mathrm{Mg \#} & \text { wt\%gl } \\ \text { RB32(3) } & - & 17,44 & 0,91 & 1,54 & 0,00 & 3,02 & 77,13 & - & - & 100,0 & 3,43 & 1,20 \\ \text { sd } & - & 0,29 & 0,01 & 0,09 & 0,00 & 0,10 & 0,26 & - & - & 0,0 & - & \\ \text { RB16 } & - & 13,75 & 2,10 & 1,75 & 0,00 & 3,53 & 78,87 & - & - & 100,0 & 3,81 & 2,10\end{array}$

\section{Ilmenite}

\begin{tabular}{|c|c|c|c|c|c|c|c|c|c|c|c|c|}
\hline & $\mathrm{SiO}_{2}$ & $\mathrm{TiO}_{2}$ & $\mathrm{Al}_{2} \mathrm{O}_{3}$ & $\mathrm{MgO}$ & $\mathrm{CaO}$ & $\mathrm{MnO}$ & $\mathrm{FeO}$ & $\mathrm{Na}_{2} \mathrm{O}$ & $\mathrm{K}_{2} \mathrm{O}$ & Sum & $\mathrm{Mg} \#$ & $\mathrm{wt} \% \mathrm{gl}$ \\
\hline RB13(3) & - & 49,49 & 0,10 & 2,22 & 0,00 & 3,75 & 44,47 & - & - & 100,0 & - & 0,50 \\
\hline $\mathrm{sd}$ & - & 0,15 & 0,05 & 0,15 & 0,00 & 0,10 & 0,13 & - & - & 0,0 & - & \\
\hline RB14(4) & - & 50,10 & 0,12 & 2,31 & 0,00 & 4,19 & 43,28 & - & - & 100,0 & - & 2,30 \\
\hline $\mathrm{sd}$ & - & 0,42 & 0,06 & 0,06 & 0,00 & 0,08 & 0,48 & - & - & 0,0 & - & \\
\hline RB15 & - & 50,47 & 0,07 & 2,43 & 0,00 & 4,86 & 42,22 & - & - & 100,0 & - & 3,00 \\
\hline RB3 & - & 48,72 & 0,07 & 1,98 & 0,00 & 3,47 & 45,72 & - & - & 100,0 & - & 1,10 \\
\hline RB77(2) & 0,0 & 0,00 & 51,06 & 0,00 & 1,78 & 4,56 & 42,85 & - & - & 100,0 & - & \\
\hline
\end{tabular}

Biotite

$\begin{array}{lcccccccccccc} & \mathrm{SiO}_{2} & \mathrm{TiO}_{2} & \mathrm{Al}_{2} \mathrm{O}_{3} & \mathrm{MgO} & \mathrm{CaO} & \mathrm{MnO} & \mathrm{FeO} & \mathrm{Na}_{2} \mathrm{O} & \mathrm{K}_{2} \mathrm{O} & \mathrm{Sum} & \mathrm{Mg \#} & \mathrm{wt} \% \mathrm{gl} \\ \mathrm{RB} 3 & 37,7 & 5,76 & 13,93 & 18,67 & 0,54 & 10,45 & 0,07 & 1,61 & 8,05 & 96,7 & 49,93 & - \\ \text { sd } & 0,6 & 0,36 & 0,26 & 0,28 & 0,05 & 0,66 & 0,05 & 0,53 & 0,30 & 0,7 & 1,22 & - \\ \mathrm{RB} 13(5) & 37,3 & 5,76 & 13,63 & 16,71 & 0,56 & 11,69 & 0,05 & 1,19 & 8,14 & 95,0 & 55,48 & - \\ \text { sd } & 0,9 & 0,38 & 0,21 & 0,48 & 0,04 & 0,67 & 0,03 & 0,31 & 0,28 & 0,4 & 1,30 & - \\ \text { RB14(3) } & 38,9 & 5,84 & 13,62 & 16,98 & 0,56 & 10,33 & 0,09 & 1,94 & 8,02 & 96,3 & 52,03 & - \\ \text { sd } & 0,5 & 0,36 & 0,24 & 0,86 & 0,06 & 0,60 & 0,07 & 0,44 & 0,31 & 1,3 & 0,20 & - \\ \text { RB85 } & 35,9 & 4,74 & 14,54 & 15,23 & 0,54 & 14,70 & 0,00 & 1,02 & 8,86 & 96,5 & 63,25 & - \\ \text { RB86 } & 40,8 & 4,74 & 15,76 & 13,03 & 0,57 & 12,89 & 0,11 & 1,61 & 8,07 & 97,6 & 63,82 & - \\ \text { RB87 } & 35,8 & 5,73 & 15,56 & 14,72 & 0,24 & 14,07 & 0,00 & 1,02 & 8,94 & 97,1 & 63,02 & - \\ \text { RB88(2) } & 40,5 & 5,75 & 14,89 & 12,68 & 0,43 & 11,58 & 0,13 & 1,98 & 8,18 & 97,1 & 61,95 & - \\ \text { sd } & 0,7 & 0,24 & 0,45 & 0,76 & 0,08 & 0,72 & 0,02 & 0,34 & 0,36 & 0,5 & 0,05 & -\end{array}$




\begin{tabular}{|c|c|c|c|c|c|c|c|c|c|c|c|c|c|c|c|}
\hline RB89(2) & 36,6 & 5,58 & 16,68 & 14,17 & 0,36 & 11,17 & 0,07 & 1,41 & 8,07 & 95,1 & 58,43 & - & & & \\
\hline sd & 0,5 & 0,11 & 0,67 & 0,57 & 0,06 & 0,25 & 0,08 & 0,05 & 0,02 & 0,8 & 0,43 & - & & & \\
\hline RB94 & 38,2 & 6,18 & 14,59 & 14,51 & 0,47 & 12,16 & 0,03 & 1,34 & 8,16 & 96,6 & 59,90 & - & & & \\
\hline RB99(2) & 36,2 & 5,54 & 15,54 & 12,34 & 0,41 & 14,70 & 0,04 & 1,22 & 8,28 & 95,2 & 67,98 & - & & & \\
\hline sd & 0,5 & 0,41 & 0,22 & 0,44 & 0,13 & 0,22 & 0,01 & 0,14 & 0,21 & 0,6 & 0,45 & - & & & \\
\hline RB100 (2) & 37,5 & 6,39 & 14,71 & 12,45 & 0,38 & 13,66 & 0,02 & 1,22 & 8,53 & 96,4 & 66,17 & - & & & \\
\hline sd & 0,3 & 0,14 & 0,90 & 0,22 & 0,14 & 0,11 & 0,02 & 0,20 & 0,13 & 0,5 & 0,58 & - & & & \\
\hline RB101 & 39,0 & 5,71 & 15,01 & 13,31 & 0,52 & 12,85 & 0,08 & 2,13 & 8,40 & 97,0 & 63,25 & - & & & \\
\hline \multicolumn{16}{|c|}{ Clinopyroxene } \\
\hline & $\mathrm{SiO}_{2}$ & $\mathrm{TiO}_{2}$ & $\mathrm{Al}_{2} \mathrm{O}_{3}$ & $\mathrm{MgO}$ & $\mathrm{CaO}$ & $\mathrm{MnO}$ & $\mathrm{FeO}$ & $\mathrm{Na}_{2} \mathrm{O}$ & $\mathrm{K}_{2} \mathrm{O}$ & Sum & $\mathrm{Mg \#}$ & $\mathrm{wt} \% \mathrm{gl}$ & En & Fs & Wo \\
\hline RB32(4) & 48,4 & 2,45 & 3,15 & 9,36 & 20,49 & 1,00 & 12,27 & 1,62 & 0,09 & 98,8 & 57,62 & - & 29,7 & 21,8 & 46,7 \\
\hline sd & 0,3 & 0,22 & 0,21 & 0,20 & 0,14 & 0,06 & 0,14 & 0,13 & 0,02 & 0,3 & 0,59 & - & 0,5 & 0,2 & 0,3 \\
\hline RB34(4) & 49,9 & 1,60 & 1,85 & 11,43 & 21,00 & 0,97 & 11,58 & 1,66 & 0,00 & 100,0 & 63,75 & - & 34,0 & 19,4 & 44,9 \\
\hline sd & 0,3 & 0,30 & 0,83 & 0,32 & 0,80 & 0,11 & 0,21 & 0,32 & 0,00 & 0,0 & 0,36 & - & 0,3 & 0,4 & 0,9 \\
\hline RB49(3) & 50,3 & 0,79 & 1,30 & 7,95 & 21,87 & 1,48 & 15,42 & 0,93 & 0,00 & 100,0 & 47,89 & 2,80 & 24,0 & 26,1 & 47,4 \\
\hline sd & 0,6 & 0,30 & 0,32 & 0,36 & 0,07 & 0,12 & 0,45 & 0,07 & 0,00 & 0,0 & 1,85 & 1,73 & 1,0 & 0,9 & 0,3 \\
\hline RB52 & 50,4 & 0,67 & 1,18 & 7,59 & 20,96 & 1,49 & 15,23 & 1,38 & 0,14 & 99,0 & 47,04 & - & 23,7 & 26,7 & 47,0 \\
\hline RB76(2) & 51,0 & 1,58 & 4,04 & 8,65 & 19,60 & 1,17 & 12,17 & 1,91 & 0,47 & 100,5 & 55,89 & - & 28,6 & 22,6 & 46,6 \\
\hline sd & 0,4 & 0,48 & 0,88 & 0,11 & 0,47 & 0,05 & 0,45 & 0,18 & 0,08 & 1,3 & 1,24 & - & 0,8 & 0,5 & 0,4 \\
\hline RB77(2) & 50,1 & 0,96 & 1,93 & 8,75 & 20,64 & 1,29 & 12,92 & 1,41 & 0,19 & 98,2 & 54,68 & - & 27,7 & 23,0 & 47,0 \\
\hline sd & 0,4 & 0,12 & 0,60 & 0,40 & 0,30 & 0,05 & 0,25 & 0,25 & 0,02 & 0,1 & 1,61 & - & 0,8 & 0,8 & 0,1 \\
\hline \multicolumn{16}{|l|}{ Feldspars } \\
\hline & $\mathrm{SiO}_{2}$ & $\mathrm{TiO}_{2}$ & $\mathrm{Al}_{2} \mathrm{O}_{3}$ & $\mathrm{MgO}$ & $\mathrm{CaO}$ & $\mathrm{MnO}$ & $\mathrm{FeO}$ & $\mathrm{Na}_{2} \mathrm{O}$ & $\mathrm{K}_{2} \mathrm{O}$ & Sum & $\mathrm{Mg \#}$ & $\mathrm{wt} \% \mathrm{gl}$ & An & $\mathrm{Ab}$ & Or \\
\hline RB4(2) & 64,1 & 0,36 & 19,64 & 0,18 & 1,23 & 0,00 & 1,50 & 7,75 & 4,14 & 98,9 & - & - & 6,1 & 69,5 & 24,4 \\
\hline sd & 0,7 & 0,14 & 0,48 & 0,02 & 0,04 & 0,00 & 0,54 & 0,20 & 0,09 & 0,8 & - & - & 0,0 & 0,0 & 0,1 \\
\hline RB5 & 64,4 & 0,44 & 19,24 & 0,17 & 0,94 & 0,00 & 1,04 & 7,76 & 4,90 & 98,9 & - & - & 4,5 & 67,5 & 28,0 \\
\hline RB31 & 65,9 & 0,20 & 19,64 & 0,03 & 1,08 & 0,02 & 0,53 & 7,72 & 5,03 & 100,1 & - & - & 5,12 & 66,41 & 28,5 \\
\hline RB32 & 67,1 & 0,18 & 20,02 & 0,00 & 0,71 & 0,03 & 0,41 & 7,80 & 4,94 & 101,2 & - & - & 3,45 & 68,13 & 28,4 \\
\hline RB34 & 63,5 & 0,33 & 19,64 & 0,16 & 0,46 & 0,25 & 1,60 & 7,64 & 6,19 & 99,8 & - & - & 2,12 & 63,82 & 34,1 \\
\hline
\end{tabular}




\begin{tabular}{|c|c|c|c|c|c|c|c|c|c|c|c|c|c|c|c|}
\hline RB51(3) & 64,6 & 0,16 & 20,24 & 0,03 & 0,95 & 0,00 & 0,44 & 7,63 & 4,38 & 98,4 & - & - & 4,7 & 69,1 & 26,1 \\
\hline sd & 0,1 & 0,01 & 0,36 & 0,02 & 0,01 & 0,00 & 0,22 & 0,06 & 0,07 & 0,5 & - & - & 0,0 & 0,4 & 0,5 \\
\hline RB99 & 64,6 & 0,16 & 20,89 & 0,03 & 1,92 & 0,00 & 0,12 & 8,40 & 3,83 & 100,1 & - & - & 8,8 & 70,1 & 21,1 \\
\hline RB100 & 64,3 & 0,23 & 20,78 & 0,00 & 1,66 & 0,13 & 0,52 & 8,26 & 4,14 & 100,1 & - & - & 7,7 & 69,4 & 22,9 \\
\hline \multirow[t]{2}{*}{ RB101(2) } & 64,1 & 0,28 & 19,60 & 0,07 & 0,78 & 0,19 & 0,73 & 7,54 & 5,53 & 99,3 & - & - & 3,69 & 64,95 & 31,4 \\
\hline & 0,7 & 0,02 & 0,12 & 0,00 & 0,04 & 0,04 & 0,16 & 0,22 & 0,06 & 0,6 & - & - & 0,12 & 0,29 & 0,41 \\
\hline
\end{tabular}

numbers in brackets indicate the number of analysis.

sd: Standard deviation

* Total Iron reported as $\mathrm{FeO}$

$\mathrm{Mg} \#=100\left[\mathrm{Mg} /\left(\mathrm{Mg}+\mathrm{Fe}^{*}\right)\right]$

wt\% glass: Clinopyroxene compositions are re-calculated due to glass contamination (see text for details)

and here we indiciate the wt $\%$ glass substracted to the original electron microprobe analysis

En, Fs, Wo: calculated as in Morimoto (1989)

$\mathrm{An}=100[\mathrm{Ca} /(\mathrm{Ca}+\mathrm{Na}+\mathrm{K})] ; \mathrm{Ab}=100[\mathrm{Na} /(\mathrm{Ca}+\mathrm{Na}+\mathrm{K})] ; \mathrm{Or}=[100 \mathrm{~K} /(\mathrm{Ca}+\mathrm{Na}+\mathrm{K})]$. End members calculated as in Deer et al. $(1972)$ 
Table 5: Experimental melt composition (wt\%) normalized to $100 \%$ anhydrous basis

Run

NNO experiments

$850^{\circ} \mathrm{C}, 200 \mathrm{MPa}, 162 \mathrm{~h}$

\begin{tabular}{|c|c|c|c|c|c|c|c|c|c|c|c|c|c|c|}
\hline & $\mathrm{SiO}_{2}$ & $\mathrm{TiO}_{2}$ & $\mathrm{Al}_{2} \mathrm{O}_{3}$ & $\mathrm{MgO}$ & $\mathrm{CaO}$ & $\mathrm{MnO}$ & $\mathrm{FeO}^{*}$ & $\mathrm{Na}_{2} \mathrm{O}$ & $\mathrm{K}_{2} \mathrm{O}$ & Sum & Mg\# & $\begin{array}{c}\text { original } \\
\text { sum }\end{array}$ & $\mathrm{Na}_{2} \mathrm{O}+\mathrm{K}_{2} \mathrm{O}$ & per-alk \\
\hline RB1(4) & 61,7 & 0,56 & 19,5 & 0,15 & 0,95 & 0,16 & 2,23 & 9,7 & 5,1 & 100 & 10,6 & 96,6 & 14,8 & 1,1 \\
\hline $\mathrm{sd}$ & 0,9 & 0,04 & 0,4 & 0,04 & 0,02 & 0,04 & 0,24 & 0,3 & 0,1 & - & & 0,5 & & \\
\hline RB2(5) & 61,7 & 0,52 & 19,5 & 0,16 & 0,87 & 0,15 & 2,38 & 9,7 & 5,0 & 100 & 10,8 & 96,7 & 14,8 & 1,1 \\
\hline $\mathrm{sd}$ & 0,6 & 0,04 & 0,4 & 0,04 & 0,02 & 0,03 & 0,06 & 0,2 & 0,1 & - & & 0,7 & & \\
\hline RB3(4) & 61,6 & 0,55 & 19,2 & 0,17 & 0,85 & 0,14 & 2,50 & 10,0 & 4,9 & 100 & 11,0 & 98,1 & 15,0 & 1,1 \\
\hline sd & 0,5 & 0,14 & 0,0 & 0,05 & 0,08 & 0,03 & 0,29 & 0,1 & 0,19 & - & & 0,4 & & \\
\hline RB4(4) & 60,9 & 0,54 & 19,3 & 0,16 & 0,76 & 0,18 & 2,51 & 10,4 & 5,3 & 100 & 9,9 & 98,9 & 15,8 & 1,2 \\
\hline $\mathrm{sd}$ & 0,3 & 0,07 & 0,3 & 0,00 & 0,11 & 0,04 & 0,04 & 0,2 & 0,1 & - & & 0,6 & & \\
\hline
\end{tabular}

$850^{\circ} \mathrm{C}, 150 \mathrm{MPa}, 233 \mathrm{~h}$

\begin{tabular}{|c|c|c|c|c|c|c|c|c|c|c|c|c|c|c|}
\hline RB25(9) & 60,6 & 0,59 & 19,5 & 0,28 & 0,87 & 0,13 & 2,62 & 10,0 & 5,4 & 100 & 15,8 & 94,5 & 15,4 & 1,1 \\
\hline sd & 0,3 & 0,12 & 0,2 & 0,03 & 0,05 & 0,06 & 0,14 & 0,3 & 0,2 & - & & 0,7 & & \\
\hline RB26(5) & 60,8 & 0,53 & 19,5 & 0,23 & 0,83 & 0,04 & 2,54 & 10,1 & 5,4 & 100 & 14,0 & 96,1 & 15,6 & 1,2 \\
\hline sd & 0,2 & 0,08 & 0,1 & 0,03 & 0,03 & 0,08 & 0,12 & 0,2 & 0,0 & - & & 0,7 & & \\
\hline RB27(4) & 61,0 & 0,48 & 19,3 & 0,24 & 0,85 & 0,20 & 2,44 & 10,1 & 5,3 & 100 & 15,1 & 93,7 & 15,4 & 1,2 \\
\hline sd & 0,3 & 0,04 & 0,3 & 0,04 & 0,10 & 0,08 & 0,16 & 0,2 & 0,0 & - & & 0,6 & & \\
\hline RB28(3) & 60,3 & 0,48 & 19,1 & 0,21 & 0,72 & 0,23 & 2,45 & 10,9 & 5,7 & 100 & 13,1 & 95,6 & 16,6 & 1,3 \\
\hline sd & 0,3 & 0,06 & 0,2 & 0,06 & 0,06 & 0,07 & 0,29 & 0,1 & 0,2 & - & & 0,9 & & \\
\hline RB29(6) & 59,4 & 0,57 & 19,8 & 0,25 & 0,61 & 0,20 & 2,70 & 10,8 & 5,7 & 100 & 14,2 & 96,3 & 16,5 & 1,2 \\
\hline sd & 0,3 & 0,09 & 0,1 & 0,02 & 0,08 & 0,07 & 0,27 & 0,2 & 0,1 & - & & 0,6 & & \\
\hline \multicolumn{15}{|c|}{$850^{\circ} \mathrm{C}, 100 \mathrm{MPa}, 195 \mathrm{~h}$} \\
\hline RB13(5) & 60,9 & 0,63 & 19,4 & 0,29 & 0,82 & 0,15 & 2,53 & 10,1 & 5,1 & 100 & 17,0 & 95,5 & 15,2 & 1,1 \\
\hline sd & 0,6 & 0,21 & 0,3 & 0,13 & 0,04 & 0,04 & 0,26 & 0,4 & 0,0 & - & & 0,7 & & \\
\hline
\end{tabular}




\begin{tabular}{|c|c|c|c|c|c|c|c|c|c|c|c|c|c|c|}
\hline RB14(1) & 60,1 & 0,41 & 19,8 & 0,17 & 1,00 & 0,06 & 2,22 & 10,8 & 5,4 & 100 & 12,1 & 93,6 & 16,2 & 1,2 \\
\hline RB15(1) & 60,8 & 0,41 & 20,0 & 0,17 & 1,01 & 0,06 & 2,25 & 9,9 & 5,5 & 100 & 12,1 & 96,2 & 15,3 & 1,1 \\
\hline \multicolumn{15}{|c|}{$850^{\circ} \mathrm{C}, 50 \mathrm{MPa}, 389 \mathrm{~h}$} \\
\hline RB31(4) & 60,3 & 0,51 & 19,5 & 0,22 & 0,71 & 0,11 & 2,79 & 10,3 & 5,6 & 100 & 12,1 & 95,6 & 15,9 & 1,2 \\
\hline sd & 0,3 & 0,05 & 0,2 & 0,01 & 0,05 & 0,08 & 0,19 & 0,3 & 0,1 & - & & 0,5 & & \\
\hline RB32(3) & 59,6 & 0,58 & 19,6 & 0,28 & 0,71 & 0,19 & 2,82 & 10,5 & 5,7 & 100 & 15,2 & 96,3 & 16,2 & 1,2 \\
\hline sd & 0,2 & 0,05 & 0,2 & 0,04 & 0,10 & 0,09 & 0,17 & 0,1 & 0,1 & - & & 0,4 & & \\
\hline RB34(1) & 58,3 & 0,65 & 20,0 & 0,36 & 0,71 & 0,31 & 3,30 & 10,9 & 5,5 & 100 & 16,2 & 97,2 & 16,4 & 1,2 \\
\hline
\end{tabular}

$800^{\circ} \mathrm{C}, 205 \mathrm{MPa}, 114 \mathrm{~h}$

\begin{tabular}{|c|c|c|c|c|c|c|c|c|c|c|c|c|c|c|}
\hline RB49(4) & 61,3 & 0,26 & 20,1 & 0,10 & 0,75 & 0,10 & 2,11 & 9,8 & 5,5 & 100 & 7,6 & 89,0 & 15,2 & 1,1 \\
\hline sd & 0,5 & 0,02 & 0,2 & 0,03 & 0,06 & 0,01 & 0,03 & 0,2 & 0,3 & - & & 0,6 & & \\
\hline RB50(3) & 60,2 & 0,24 & 19,5 & 0,06 & 0,66 & 0,12 & 2,28 & 11,4 & 4,4 & 100 & 4,8 & 90,7 & 15,8 & 1,2 \\
\hline sd & 0,2 & 0,04 & 0,1 & 0,03 & 0,05 & 0,08 & 0,14 & 0,1 & 0,1 & - & & 0,1 & & \\
\hline RB51(3) & 59,5 & 0,30 & 20,0 & 0,12 & 0,57 & 0,18 & 2,95 & 10,8 & 5,5 & 100 & 6,7 & 95,1 & 16,3 & 1,2 \\
\hline sd & 0,5 & 0,06 & 0,2 & 0,02 & 0,05 & 0,04 & 0,23 & 0,1 & 0,3 & - & & 0,7 & & \\
\hline RB52(3) & 59,7 & 0,44 & 19,8 & 0,10 & 0,67 & 0,08 & 2,25 & 11,0 & 5,8 & 100 & 7,5 & 95,5 & 16,7 & 1,2 \\
\hline sd & 0,3 & 0,08 & 0,3 & 0,04 & 0,04 & 0,05 & 0,49 & 0,6 & 0,3 & - & & 0,8 & & \\
\hline \multicolumn{15}{|c|}{$800^{\circ} \mathrm{C}, 100 \mathrm{MPa}, 145 \mathrm{~h}$} \\
\hline RB61(1) & 59,3 & 0,43 & 19,1 & 0,26 & 0,59 & 0,18 & 2,67 & 11,7 & 5,8 & 100 & 14,8 & 96,6 & 17,5 & 1,3 \\
\hline RB62(1) & 58,8 & 0,43 & 19,4 & 0,25 & 0,80 & 0,15 & 2,32 & 11,6 & 5,9 & 100 & 16,0 & 96,6 & 17,6 & 1,3 \\
\hline
\end{tabular}

$900^{\circ} \mathrm{C}, 200 \mathrm{MPa}, 164 \mathrm{~h}$

RB85(4)

60,6

0,72

19,6

$\begin{array}{lllllll}9,4 & 5,3 & 100 & 16,2 & 93,6 & 14,7 & 1,1\end{array}$




\begin{tabular}{|c|c|c|c|c|c|c|c|c|c|c|c|c|c|c|}
\hline $\mathrm{sd}$ & 1,0 & 0,08 & 0,1 & 0,02 & 0,09 & 0,18 & 0,36 & 0,6 & 0,1 & - & & 0,4 & & \\
\hline RB86(4) & 60,2 & 0,70 & 19,6 & 0,30 & 0,90 & 0,33 & 2,81 & 9,6 & 5,5 & 100 & 15,9 & 94,0 & 15,1 & 1,1 \\
\hline $\mathrm{sd}$ & 0,3 & 0,13 & 0,3 & 0,03 & 0,02 & 0,09 & 0,33 & 0,2 & 0,2 & - & & 0,7 & & \\
\hline RB87(5) & 60,3 & 0,64 & 19,7 & 0,30 & 0,99 & 0,16 & 2,66 & 9,8 & 5,4 & 100 & 16,8 & 95,0 & 15,2 & 1,1 \\
\hline $\mathrm{sd}$ & 0,1 & 0,07 & 0,2 & 0,05 & 0,02 & 0,16 & 0,16 & 0,0 & 0,1 & - & & 0,7 & & \\
\hline RB88(3) & 60,3 & 0,65 & 19,5 & 0,27 & 0,94 & 0,23 & 2,65 & 9,9 & 5,5 & 100 & 15,5 & 94,6 & 15,4 & 1,1 \\
\hline $\mathrm{sd}$ & 0,5 & 0,01 & 0,2 & 0,01 & 0,04 & 0,10 & 0,12 & 0,3 & 0,1 & - & & & & \\
\hline RB89(3) & 60,6 & 0,65 & 19,8 & 0,28 & 0,92 & 0,30 & 2,38 & 9,6 & 5,5 & 100 & 17,6 & 95,6 & 15,0 & 1,1 \\
\hline $\mathrm{sd}$ & 0,2 & 0,08 & 0,0 & 0,00 & 0,06 & 0,06 & 0,43 & 0,2 & 0,0 & - & & 0,5 & & \\
\hline RB90(4) & 59,7 & 0,58 & 19,6 & 0,28 & 0,85 & 0,16 & 2,89 & 10,2 & 5,8 & 100 & 14,6 & 96,7 & 15,9 & 1,2 \\
\hline $\mathrm{sd}$ & 0,4 & 0,07 & 0,3 & 0,01 & 0,05 & 0,11 & 0,22 & 0,4 & 0,2 & - & & 0,6 & & \\
\hline \multicolumn{15}{|c|}{$900^{\circ} \mathrm{C}, 100 \mathrm{MPa}, 188 \mathrm{~h}$} \\
\hline RB 91(4) & 60,0 & 0,71 & 19,7 & 0,33 & 0,97 & 0,16 & 2,91 & 9,6 & 5,4 & 100 & 16,8 & 95,4 & 15,0 & 1,1 \\
\hline sd & 0,4 & 0,05 & 0,3 & 0,04 & 0,10 & 0,07 & 0,20 & 0,4 & 0,2 & - & & 0,6 & & \\
\hline RB 93(3) & 60,6 & 0,65 & 19,7 & 0,30 & 0,89 & 0,20 & 2,35 & 9,5 & 5,5 & 100 & 18,8 & 96,3 & 15,0 & 1,1 \\
\hline sd & 0,1 & 0,09 & 0,1 & 0,04 & 0,09 & 0,16 & 0,31 & 0,3 & 0,1 & - & & 0,7 & & \\
\hline RB 94(6) & 60,4 & 0,58 & 19,5 & 0,29 & 0,99 & 0,17 & 2,84 & 9,6 & 5,5 & 100 & 15,4 & 96,3 & 15,1 & 1,1 \\
\hline sd & 0,1 & 0,12 & 0,2 & 0,03 & 0,05 & 0,18 & 0,13 & 0,1 & 0,2 & - & & 0,4 & & \\
\hline RB 95(3) & 59,7 & 0,60 & 19,6 & 0,31 & 0,95 & 0,20 & 2,69 & 10,1 & 5,6 & 100 & 16,8 & 97,7 & 15,7 & 1,2 \\
\hline sd & 0,4 & 0,02 & 0,3 & 0,03 & 0,10 & 0,18 & 0,40 & 0,4 & 0,2 & - & & 0,1 & & \\
\hline \multicolumn{15}{|c|}{$900^{\circ} \mathrm{C}, 50 \mathrm{MPa}, 284 \mathrm{~h}$} \\
\hline RB 96(4) & 60,1 & 0,60 & 19,8 & 0,31 & 0,95 & 0,20 & 2,71 & 9,5 & 5,6 & 100 & 16,8 & 97,0 & 15,1 & 1,1 \\
\hline sd & 0,4 & 0,05 & 0,2 & 0,02 & 0,07 & 0,12 & 0,45 & 0,4 & 0,2 & - & & 0,8 & & \\
\hline RB 97(5) & 60,2 & 0,70 & 19,6 & 0,40 & 0,83 & 0,17 & 2,88 & 9,4 & 5,6 & 100 & 19,8 & 97,7 & 15,1 & 1,1 \\
\hline sd & 0,5 & 0,09 & 0,1 & 0,02 & 0,06 & 0,07 & 0,38 & 0,3 & 0,1 & - & & 0,6 & & \\
\hline RB 98(5) & 59,9 & 0,72 & 19,6 & 0,42 & 0,86 & 0,18 & 2,93 & 9,5 & 5,6 & 100 & 20,2 & 97,9 & 15,1 & 1,1 \\
\hline sd & 0,3 & 0,09 & 0,1 & 0,07 & 0,03 & 0,06 & 0,27 & 0,2 & 0,1 & - & & 0,5 & & \\
\hline RB 99(5) & 59,5 & 0,69 & 19,6 & 0,42 & 0,83 & 0,11 & 2,80 & 10,3 & 5,7 & 100 & 21,1 & 97,6 & 16,0 & 1,2 \\
\hline $\mathrm{sd}$ & 0,3 & 0,13 & 0,1 & 0,03 & 0,03 & 0,09 & 0,22 & 0,2 & 0,1 & - & & 0,4 & & \\
\hline
\end{tabular}




\begin{tabular}{|c|c|c|c|c|c|c|c|c|c|c|c|c|c|}
\hline RB 100(5) & 58,8 & 0,69 & 19,4 & 0,46 & 0,79 & 0,18 & 3,00 & 10,5 & 5,8 & 100 & 21,5 & 97,8 & 16,4 \\
\hline sd & 0,4 & 0,05 & 0,2 & 0,06 & 0,05 & 0,09 & 0,30 & 0,2 & 0,1 & - & & 1,3 & \\
\hline RB 101(5) & 58,7 & 0,70 & 19,6 & 0,46 & 0,78 & 0,17 & 2,60 & 10,9 & 5,9 & 100 & 24,0 & 98,4 & 16,8 \\
\hline de & 0,4 & 0,06 & 0,2 & 0,05 & 0,04 & 0,07 & 0,11 & 0,3 & 0,2 & - & & 0,7 & \\
\hline
\end{tabular}

\section{QFM experiments}

$850^{\circ} \mathrm{C}, 100 \mathrm{MPa}, 188 \mathrm{~h}$

\begin{tabular}{|c|c|c|c|c|c|c|c|c|c|c|c|c|c|c|}
\hline RB 73(3) & 60,8 & 0,48 & 19,9 & 0,18 & 0,92 & 0,17 & 2,61 & 9,4 & 5,6 & 100 & 10,8 & 93,7 & 15,0 & 1,1 \\
\hline sd & 0,3 & 0,03 & 0,0 & 0,03 & 0,06 & 0,15 & 0,09 & 0,1 & 0,2 & - & & 0,9 & & \\
\hline RB 74(3) & 60,5 & 0,41 & 20,0 & 0,21 & 0,79 & 0,24 & 2,78 & 9,4 & 5,7 & 100 & 11,9 & 93,9 & 15,1 & 1,1 \\
\hline sd & 0,3 & 0,03 & 0,0 & 0,03 & 0,06 & 0,15 & 0,09 & 0,1 & 0,2 & - & & 0,8 & & \\
\hline RB 75(3) & 59,8 & 0,50 & 20,0 & 0,19 & 0,88 & 0,23 & 2,62 & 10,2 & 5,6 & 100 & 11,5 & 95,0 & 15,7 & 1,1 \\
\hline $\mathrm{sd}$ & 0,3 & 0,03 & 0,0 & 0,03 & 0,06 & 0,15 & 0,09 & 0,1 & 0,2 & - & & 0,9 & & \\
\hline
\end{tabular}

numbers in brackets indicate the number of analysis

All analyses are normalized to $100 \%$ anhydrous. Original totals are reported (original sum) sd: standard deviation

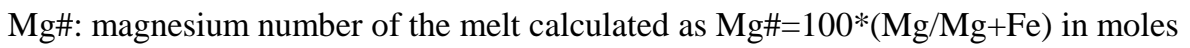
per-alk: per-alkalinity calculated as $(\mathrm{Na}+\mathrm{K}) / \mathrm{Al}$ in moles

$\mathrm{FeO}^{*}$ : Total iron reported as $\mathrm{Fe}^{2+}$ 